University of Louisville

ThinkIR: The University of Louisville's Institutional Repository

1932

\title{
The effect of sodium chloride upon the fission rate within a single clone of Paramecium caudatum and the heritability of that effect.
}

\author{
Mary C. Adolph \\ University of Louisville
}

Follow this and additional works at: https://ir.library.louisville.edu/etd

Part of the Biochemistry Commons, and the Cell Biology Commons

\section{Recommended Citation}

Adolph, Mary C., "The effect of sodium chloride upon the fission rate within a single clone of Paramecium caudatum and the heritability of that effect." (1932). Electronic Theses and Dissertations. Paper 1684. https://doi.org/10.18297/etd/1684

This Master's Thesis is brought to you for free and open access by ThinkIR: The University of Louisville's Institutional Repository. It has been accepted for inclusion in Electronic Theses and Dissertations by an authorized administrator of ThinkIR: The University of Louisville's Institutional Repository. This title appears here courtesy of the author, who has retained all other copyrights. For more information, please contact thinkir@louisville.edu. 
UITVESITY OF LOUSVILW

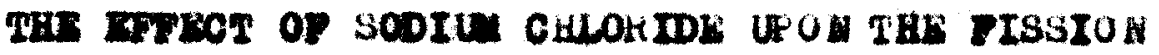
KATE WITHIX A SILLW OLONE OP PAKAMEOIUU CAUDAI U AD THE HWITABILITY OP THAT HWWOT

\author{
A DLeartation \\ Bubnttied to tho mouzty

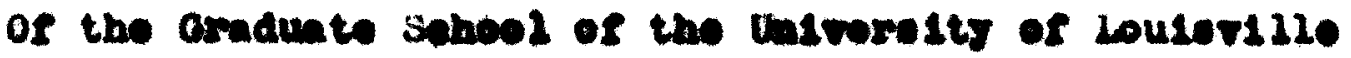 \\ In Partial ruxplzmat of tho \\ Kogutromente for the Degree \\ Of Mater of salonse
}

Departmont of Blolog

by

wary 0. A602ph

2038 
My deep gratitude is due Dr. All tin K. Middzeton, for his practoun guldabee and oonetructivo eritielom of thie vork. Dr. Middoton has given unstintingly of the resulte of his mimerous re- earohes done w1thla the olone of rerapectu

geudatug. and thie work 10 bereby dedieated to him. 
comisns

Page

2. Introduotion -

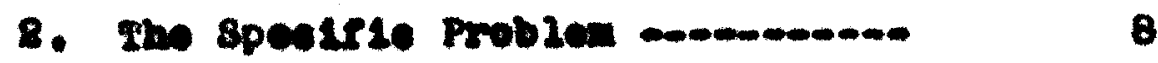

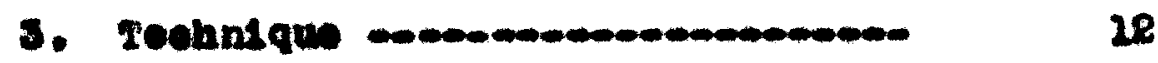

4. Experimonte to teat tho efreet of sodile ehjorlde on the rieston rate mathin a elngle clope of Rarante equatie.

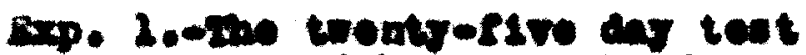
ponsed betweon the control and reparsentel cote of Bexmenty.

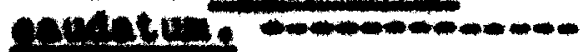

82

Ixp. 8,-200 benty aday teot parted between the control and the Dupleate an.

portmontad sote of

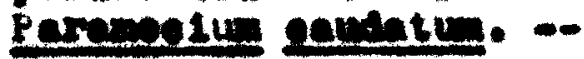

Dep. 8.* the trenty - day teet peried botreen the properimontal and Dupluate eapertmontal cote of Pareme-

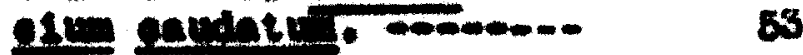

6. Summiry 70

6. H1b210graphy and 73 
INTRODOCT 103 
Inherited charecteristies have beed found remarkably constant in organiem multiplying without admixture of two perente that differ in hereditary onstitution. Wot of the recent work agrees that in euoh unirarental reproduetion, Ioherited rariatlons occur rarely or not at ali, and that seleotion has practically no effect in eltaring racial oharacteriation.

A certein number of obervation bave beon wade which bear on the inneritance of the fisston rate and on the quedion whether thare are difforences among the progeny of alngle individual La respeot to these. Mupas (25) made exten 17o studies of the efreote of temperature and of other condition on fission rates of paramiecium caudetum. He was courlues from the result of his studies, that under given conditions the fiselon rate is uniform in ell progeny of given individuel, and that Inherited variation in the rate do not oceur In suoh pure race or within a single olone. On this subjeot, his conoluslona are in complete harmony with those of the 'pure $11 n$ ' workere. He summarisen his results foilowis: 
"In 211 my oulturee I have always seen all the norma 1 descendents of the wane anewtor, grow and nultiply with the wost perfeot uniformity. I have become convinoed of the lutegral transmasion of the raculty of developsent from one generation to another, and the mont complete phyolologleal equivplence must exist among all the bormel individuale produced in tha eusoeselve generation.

In long and nwmerou experimerti on fifteen to twents specles, I hare never oberved anything which permita belief in the exiaterce of morphological and physlologleal differonoes, not merely botweon the two producte of given fiasion, but evon among

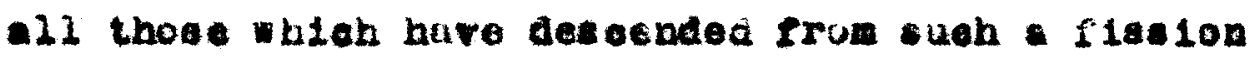
by regular atid continoks gereration."

a paper of Jetnange (1i), Likcwive dea lo to oertacir extert with thio abject. He atas that in a Nla population, many straiue differing in rate of Ission (under the same couditions) were found to ocour. Fatherniore, it was danous tratca tnct even in a population derived by fiseion from single indiviaual In a pure strain, conjugation produced inhorited difference in the fission rate. After conjugation there 
were presont train showing constent differenoes In fiseion rate. On the other hand. If no oonjugation has oecurred anong the procen of a single indisidual, the fistion rate was found to be nearly uatform.

calklin and Grogory (3) state that there are In many eased difforenees in the fiasion rate amoug the four sete of progeny rooulting from the firet two division of an indiriduad thet has jut eonjugatoa.

Wen condition aro not uniform, the rate of rieston 111 not be unferi in all the progeng of a given individual. then the progew of atngle paramealum are put into different culture media, under constut conditions, line fiselat rate of the paramecia w111 differ ecordang to the nedium usea. 
2W0 SPDETVIO PKOSLEN 
Thon a Ingle paramecien divide, often one of Its two preger agnin dividee before the othar does.

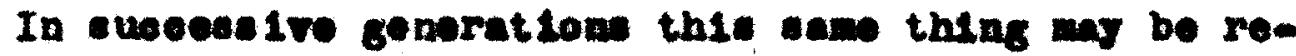
peated. Pigure $X$ shome thet anong the progong of a -1nglo indstidind at a given womot, thore nay oceur animale that are the produate of fow and othore that are the producte of two flosion. Hone there aro difforenes of flesion rate anong the dosesndante of

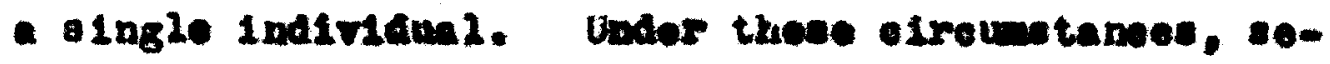
lootion for olther saut or elor rate of fisaion is unavoldatio. Midazeton (26) by his devise of 'bal-

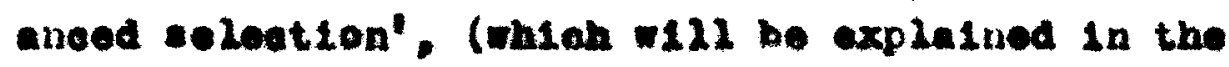
disouseson of technique) eliminated this seleotion. Th1e opeced the posesbility of more aceuratedy tentIng the efrecto of environmentad factore upon the hereditary fianion rate. The firet of these studies was that of ulddioton in whiob it was sown that temperature difforonees produes heritable differenoes in the fiesion rate. Ho has shemp aleo that organio and inorgante substanece wodiry horeditarily the fles10n rate.

This atudy conelder the erfect of codium obloride upon the fiselon rate within a eingle olone of Paramedum 


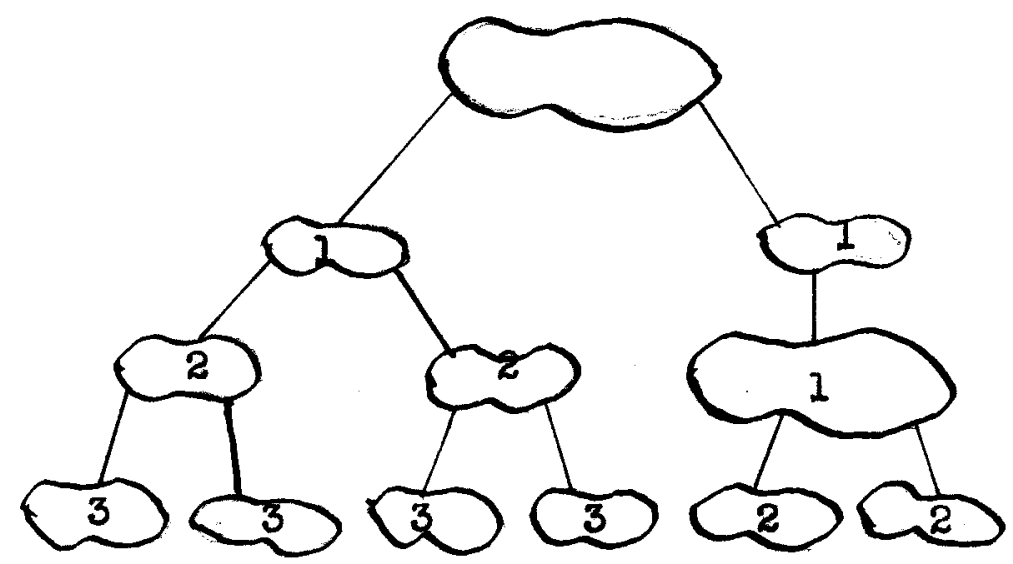

Hgure 2 showe the aucoeselve pistions among the progeny of tao indivituals, thet et s given momont we way have, among the progers of thete tro narents, Lidividula of the seond for the thire gresations which are indistiaguishablo. The numbers fithin the outlines of the animale indisate the number of flselone whioh hare interrened between 1 ind its or 1 gnal purent. 
eaudatum, and the heritab111ty of that affeet.

The preasent paper ia a statement of the rosults of a series of experiments dosigoed to throl light upor ths question of the posalbility of modifylag $1181 \mathrm{ag}$ eystems by environamtal factors - that the modsflestion porelat lin liter joneratione in the abence of the faotor which orought forth the modifloation. Can the 1ndividual, by -ubjeeting it to the jodium ohioride oulture nedium, beoome so ohenged that the changen gorelst through later generationes 
morutau 
Uis Septemier 21, 1931, a singit parameolum gauainun was isolated. OH jept ember 26, 193I, forty lakividuals, all of the oighth generation. acre ublaticed.

Ihe almale were oultivated on ground-glane

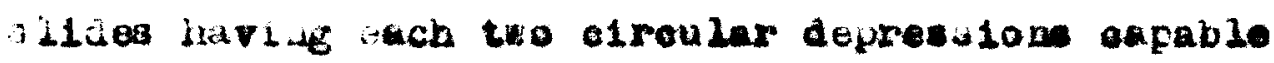

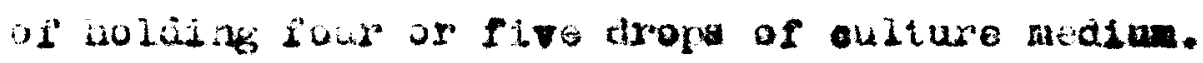

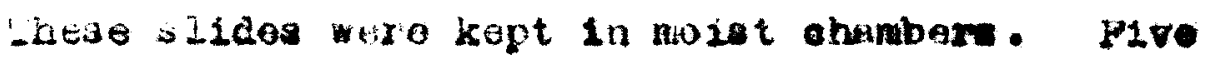
aropo of chlture nedium were used in ean depression

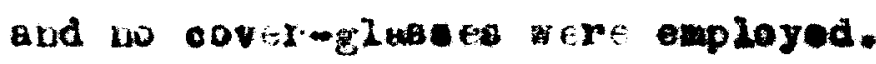

Iable I show s how the parameela were seleoted datly la ordar to obtain elone all of the samo gonerat10a.

2weaty two-groove ground-giand allde were

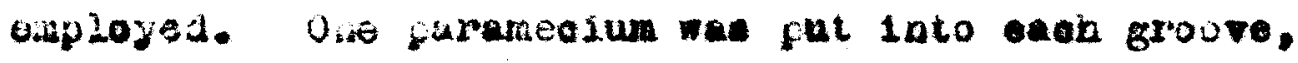
thus mistig foxts individuals. The folloding day. a alaglo perameotum was selectud from among tho progeny of each of these and put into each groove

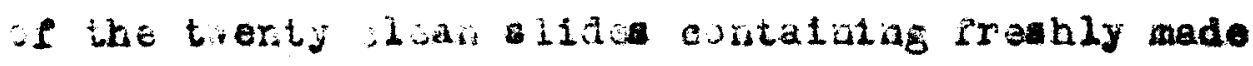
eulture modia.

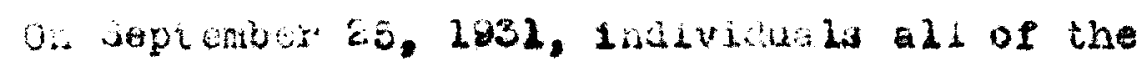
- Ighth gentration were weeured. 
$2 a b 2 \cdot 2$

The eally celection of Paremeels pavdatu for the

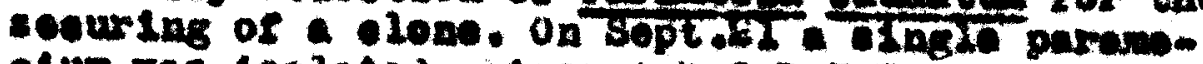

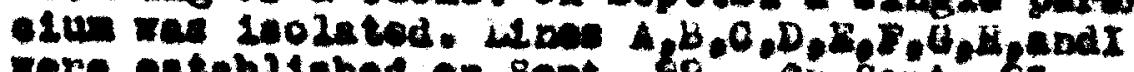

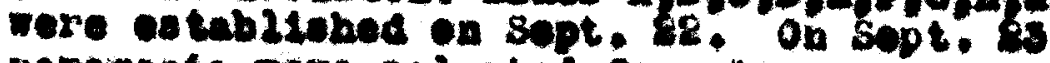
paramale were celeoted from 41 w D. Fhrough the

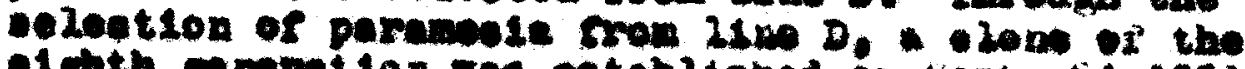

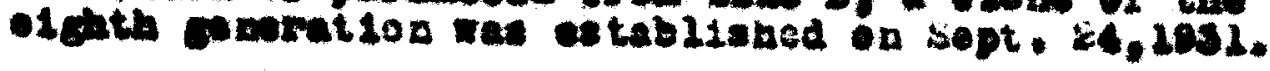

sept. 28, 2018.

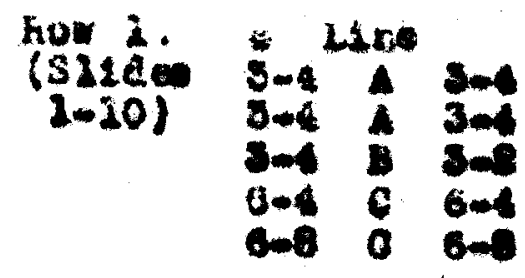

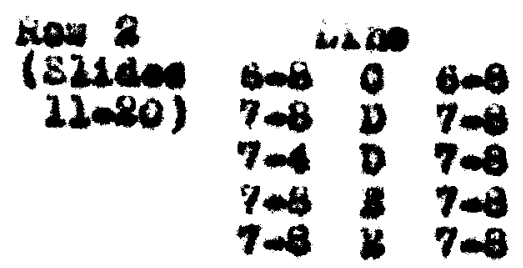

sopt. 09.2082.

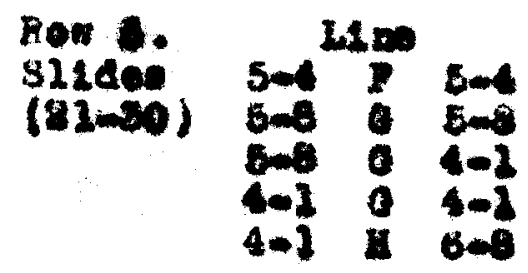

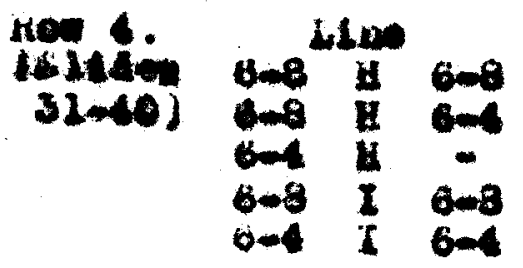

3opt. 23,2981 .

\begin{tabular}{|c|c|}
\hline $\begin{array}{r}\text { Kew } 2 . \\
(312 d 0) \\
(1-20)\end{array}$ & 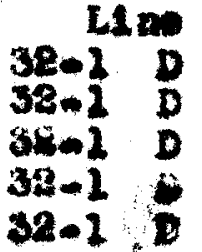 \\
\hline
\end{tabular}

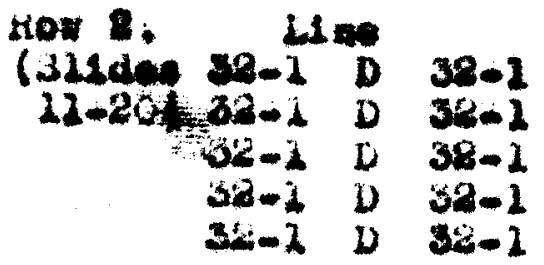

Sept. 84,2032.

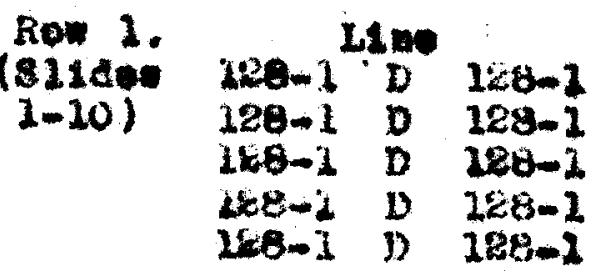

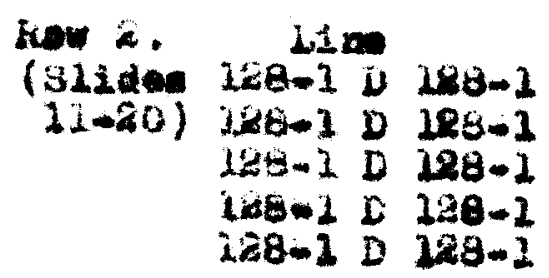

WLescios rate of parabeda 
of the forty lindividuald thu obtalata, tasnty were plaved 1 is a $1 / 16 \%$ solition of dorlieks Malted Milk aliture. This oulture nediun as mado by diasolving owe-hwif eran of the malted mat youder in 60 o.c. of bolling dist1lled water. Six and twothirde c.a. of thia solution ware next diluted to 1000.0 . With builiag distizied water, making $1 / 26 \%$ soiution. Wha solition mas cooled bafore usiag. This oulture medifure was wed for the sontrod and dupilento-experimestid lives. The remaining twenty parameela wero 1wolnted intiariy in 2/26\% Horliok's Halted Hije soluticn. but in tha properation of this

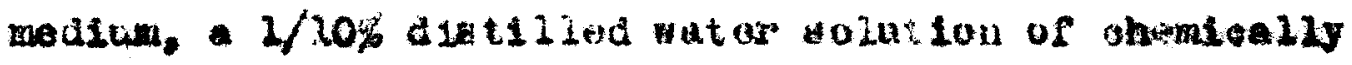
pure sodiva chloxide wat used as the soiveat of the

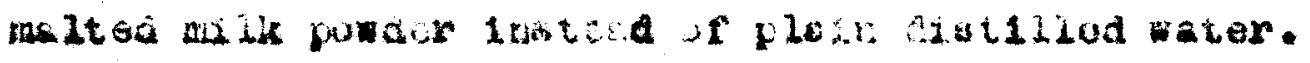

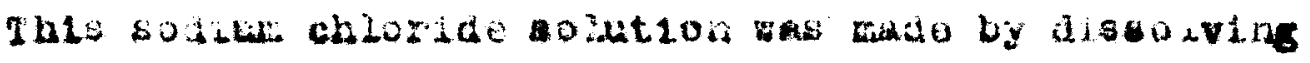
one Parke Lavis oudum chloride tablet in folur fluid ounces of dist126d water. Igenty-pive e.c. of this aline oolution was dilited to LbU 0.0 . With distilied water, making a $1 / 10 \%$ solution whioh was used for the experimeutal 21aed. Each day a fresh $1 / 20 \%$ malted milk aod Lur ohlorise solution was made.

The alldes of the o ontrol and exporlineatul lines were so arranged, that sllde wo. I of the experimental set corresponded with slide wo. I of the control set, and $s$ on throughout the ter sides of the two sets. 
Figure 2 11lustrates the correspoudenee of the slides of the tro sets.

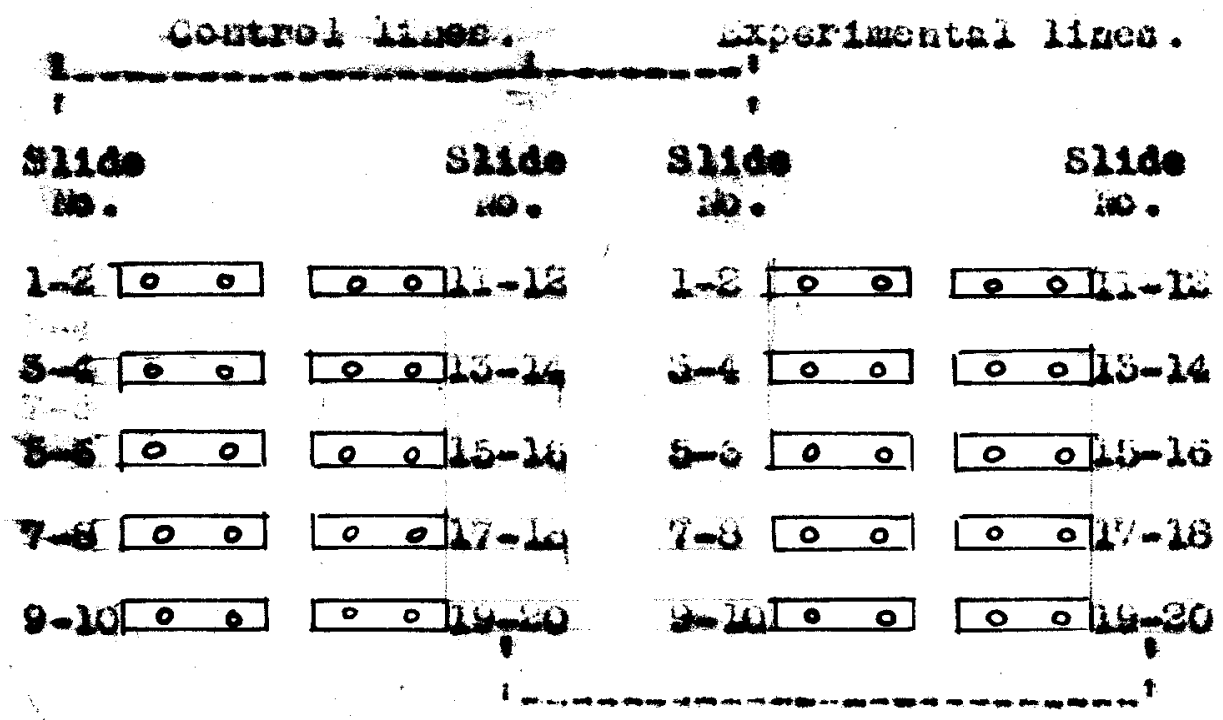

Figure 8 abow how the Bildes of the eontrol and experimeatal o ot nere arrauged so that olide wo. I of the experimental set corresponded with side to. I of the control set, and so on throughout the ten lides of the two ete.

lanc were tenty corresponding lines establiahed in the two sote.

sech Bllde contalned two 21nee, sinae there was one line in each of the two grooves. An individual of the same line was put into - lide to. I of the experimental set as into lide No. I of the control set. Likew1se with sildee 2-3-4 eto. 
Lixemlse the parenecte of the Gxortmontal and Later of the duplicate exprofmental sots nowe changed datly to frob caltire sldes of thelr ons peta.

The duglentes of tho oxparinentel llees aro referrea to throughout this tady as tho dupliesteexporiatental I1nes.

The coutrol aid arporinoutel set ran for 3 period of torty-five deja. At the ond of tho furth day, the exporimertal st nso cuplioatod. Ihis oet wes torines the dupliants experibuatal sot. Ihe paramocio nich aere tranferred from tho sodiun ohlorice oulture medilim of the experinontal set, were pit 1nty the $1 / 16 \%$ meltod milk oulture medium.

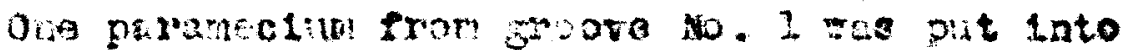
corsogending groove it. I of the goneh alide. If

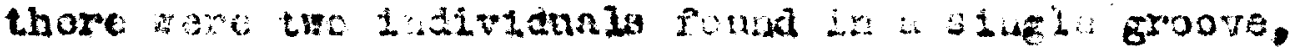
the slad was number 2-1. whis ngoord meaning thet thoro were tzo individuals restiting from ono fiasion. If thore ere four prisinoosa of the same ase in the grove, the alldo was laivelied s-2. meanlag that there were four individualis resulting from two fisalona. If there were three paramoda, one larzo and two snall 1 adividugls in the groove. 1t meant that there had boen two flesion, the original 
Inatvidval dividiag once, maktag tro individnels, and then the divictig of ondy one of these two

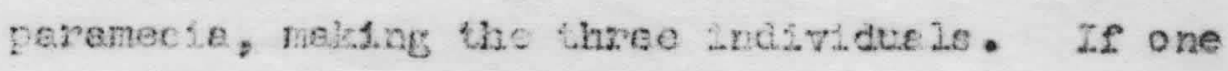
of the smallom individuals ras solected, tho silee ves maked BnA S., neaning that s shor solection was to be rade for thet 32 bo at tho reot oppor-

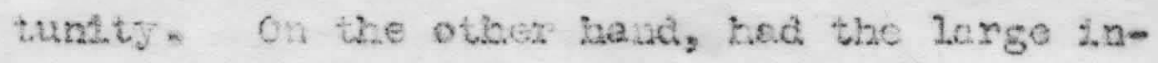
dividuel boeri seleatch, whe shide rould have been nerked $3-25 \%$, destemting that tho next selection ras th be a rast ona.

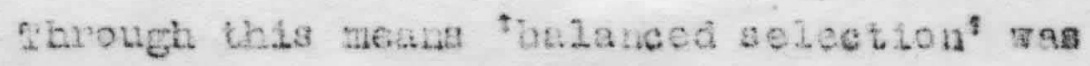
as aured thwought ali ilues, "BaLanced selection' th tho groces of compensting for the ofrect of ovory selection that one is conpelied to maze by nokgh the reverse selootlon at the bazt opjortuntty; 1.n other poros, one wales tho same number of plus and nithas solections th ang blvea line during each suacessive tho intervad ettoptoc.

Fhe anat obviow nethed whthout 'balanced selection' Might have been to seleot ald Llwes, both experimental and control for fest rate. but, under such a procedure, 1. there was an offeot of the sodium ohloride slowing the fisston rate of the exporinontal ities, there woulc be an opportunity fur more sequent selections 
In the control 11us, On the ather hand, should the bodiun chloride ine tesso the fissioa rato of the oxporsmental Lises, then thes revere would be whe caso. In elchos case, hils prucecure would at roveal the trite offect of the sotfum daloride

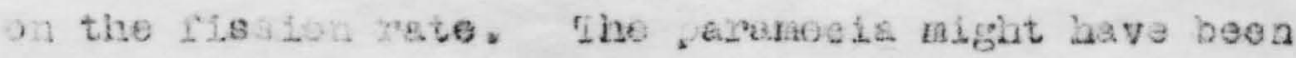
seleoted at ructon, fusultug fa ad untrue balanse at the ont of the heat puriod.

It orecr thit regulte meg bo of vatuo, ousAitions aw be watrow throughout. In adaing to the unilar bitg of conditious, idmperablure and

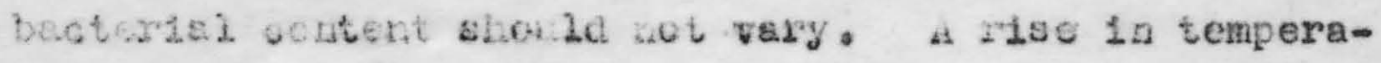
ture Lucreases the plabion rate; in very warn woather fisstor rate is cobicerably aceelerated. On the other heid, a drog it temperacure, dearcaes the $113 a 100$ rate.

If the baberiai content baconcr too great, the Ilssion rate deaidased one-coiled onimals or plants abretiacs destroy the paramecia. Uniformily of baterial aontent in the culture nedie was secured bo washing the peranteoia, at eertain intervals, In freah culture nedum before transferring them to a was slide, the gareinecla nere ablowed to remain \{uaglig ton whuzes) in the sed mediun in order 
to wast tamselves as free as foselblo of bactorla. whoy are thea tracuferred to new oulture medis on the definitive olide. Ihe pipette used in transferring tat inglyiduals mas lavariably aterillsed In bolllag distilied weter after enoh trangfer, thw grevariag the andrteational introduction of any iraivizual whion might oling to the pipetto. The - Llaes are labelied lis soft lad pencli; the nuber

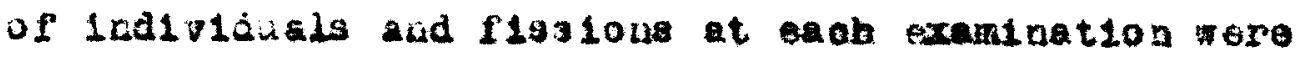
likewiso recurded on them, to be later traneforred to permanent recordo.

The Ildee nere examined deliy at approximately the anc time o that there would not be a longer period owe day and shorter one on the following and 
DXP ER IMENT I 


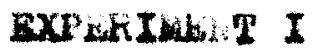

A eopperison of the fleston rate of the control at with that of the experinontal wet for

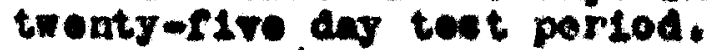

(sopt. 25-00t. 29,2052)

On September 25, 2081, forty Parames sa cadatu, a22 of the elgith goneration, more loezated on

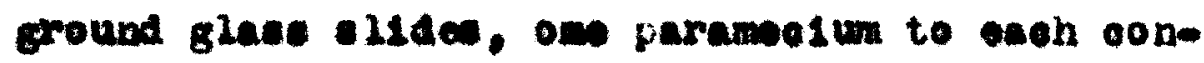
arvits. thu arvalng the forty paramente into two groupe of tronty anch. On group we kept as the

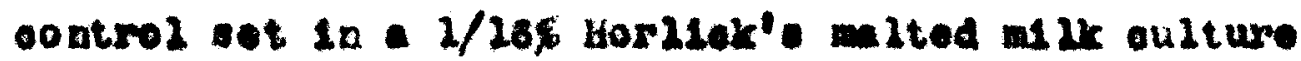
malum. the other to be destgrated as on experimontal

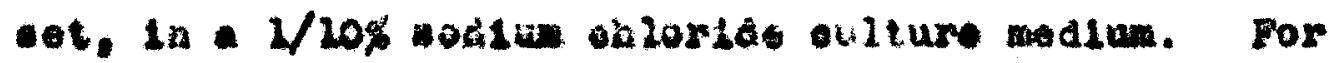
twenty-flve daye, those twerty contwol lines ard trenty experzmental ilnow wore fropogeted with bal. aneed eelention'.

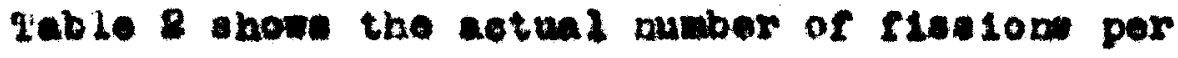
Iremang ported per ine in the cotitrol and experimental sete. Then the alfrerenees per 11 a por Itro-dey porled of the forty lines are average, It showe that the eontrol linos produed .35 fiselon wore Whan the everage for the expertwental $21 \mathrm{ne}$ in the flrot riveng poriod. .66 goneration more in the ceeond fromdiy pertod, 3.68 sonerntion moro in the thire flwe-an perlod. 3.26 genoretione more in the fourth e1vemday pertod, and 5.16 generation 
Table 2

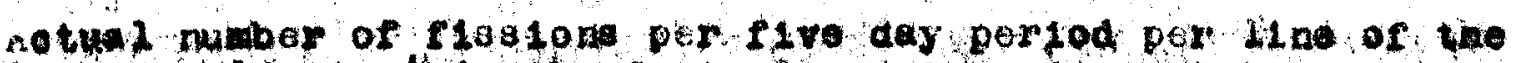

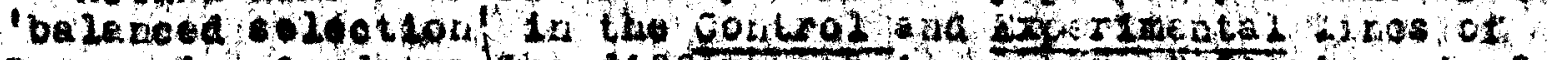

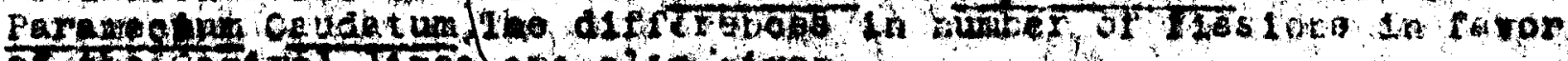

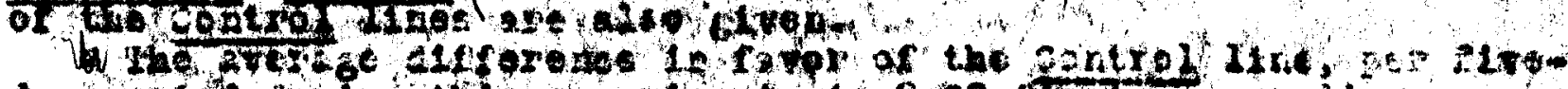

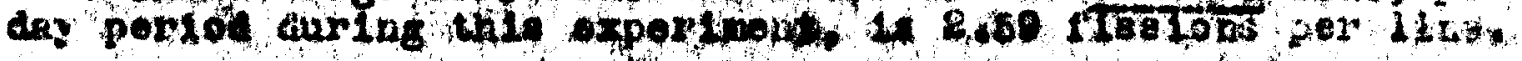

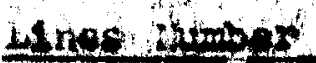

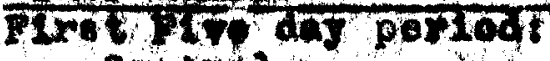

contiob 2 !

Exp antmantal

6

Befranonos $-8$

1

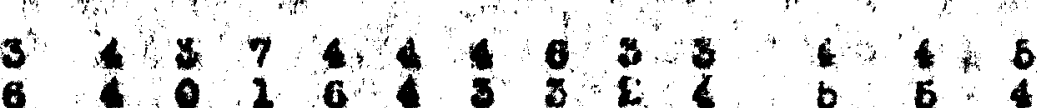

$8 \quad 0,36-2$

02

Seqont 5-day purlod

Controm

042547542676

Exporinointal

6

6. 2.34034

infromena $-6 \quad-2 \quad 0-2$

$2,42-4$

$2,7 \quad 3 \quad 2$

Intre ptwe en pertod comerol

6

Raportmontal

8

DLPerome:

3

6. $67 \begin{array}{lllllllllll} & 8 & 5 & 7 & 7 & 8 & 5 & 7 & 9 & 6\end{array}$

40236252522

$320-20,54022505$

Fonith siday perlod: esntrol

$57 \% 6467865 \% 5$

Hopertuntal

$\mathbf{s}$

344225212535

Dteromano

2

9

Fifth plov dey period: control

87.86060 .6775129

expertmentai

3.

Dtrerenae

6

3 222

8

2.2

$\therefore$

233

64756476,5

Cherodohos rot tho

whole 28 deys.

$21420+112721 \quad 1320 \quad 13 \quad 10 \quad 18$ 
Table 2

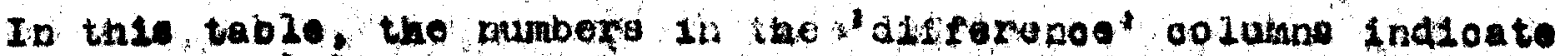

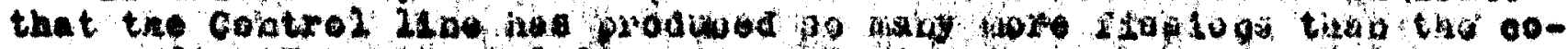

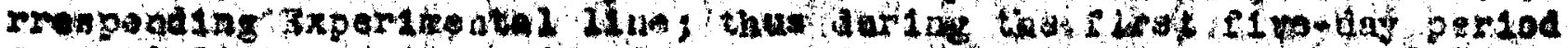

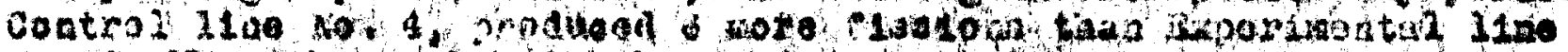

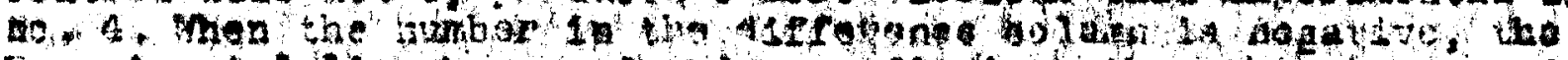

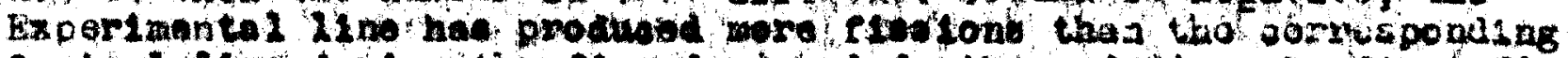

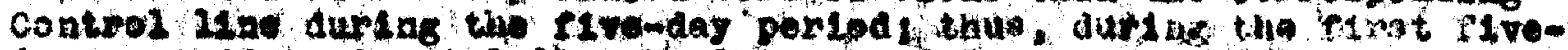

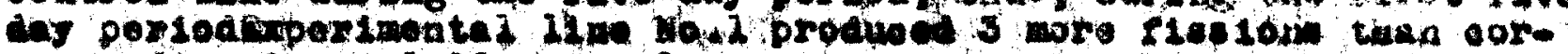

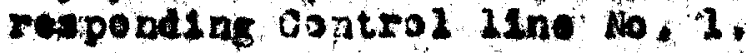

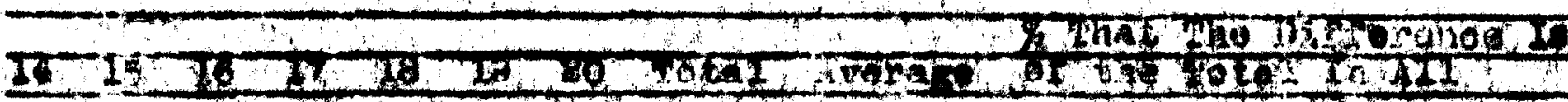

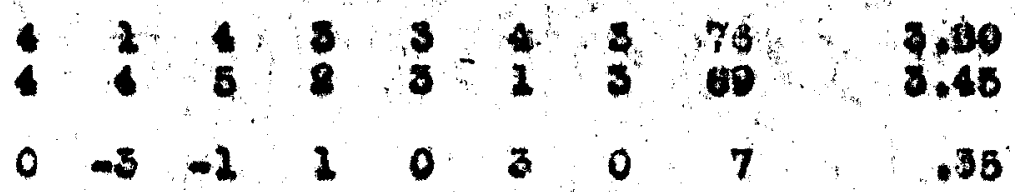

.083

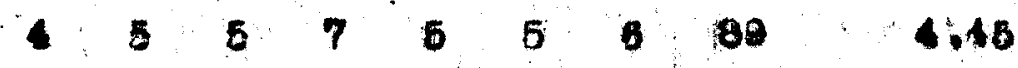

6565676.50

$-2010000$

.692

878 8 608290

2. $22541562,8.66$

$\begin{array}{lllllllll}7 & 6 & 2 & 6 & 8 & 6 & 6 & 73 & 3.66\end{array}$

4.17

$\begin{array}{lllllllll}6 & 5 & 6 & 6 & 6 & 6 & 7 & 227 & 6.86\end{array}$

$85.5 \% 28.70$

$33032+8$ c3 3.15

.363

B $\quad 8 \quad 20 \quad 8 \quad 20 \quad 7 \quad 242 \quad 7.10$

4 2 312830108

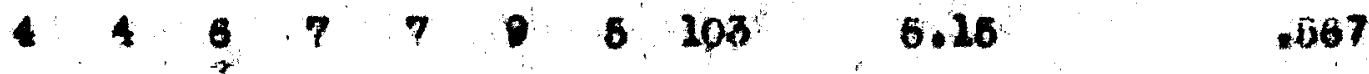

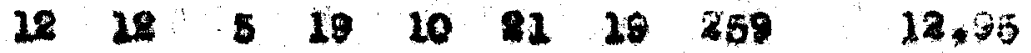




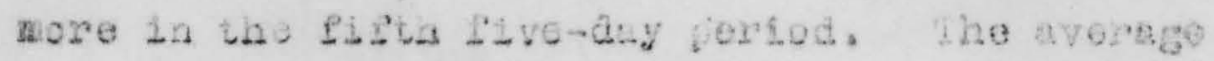

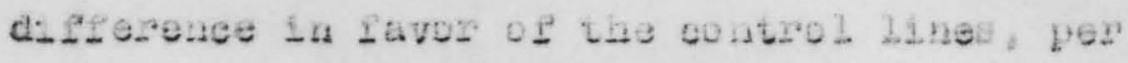

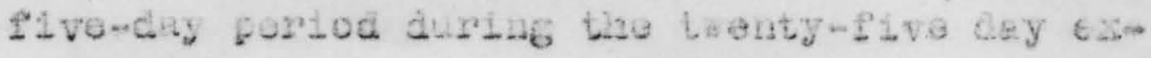

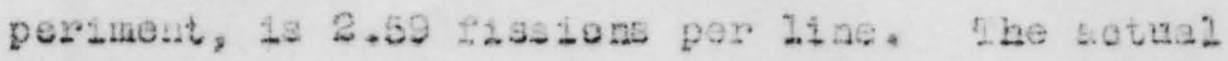
total difforonee por thorud lines por Eive-dey

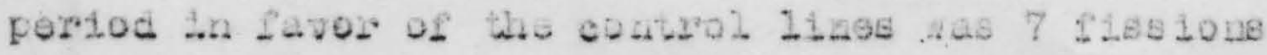

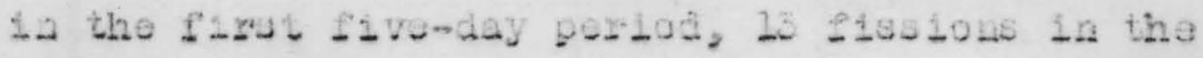

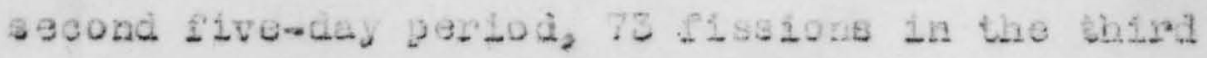
flve-day portod, 63 floglous in tho fowath fire-day

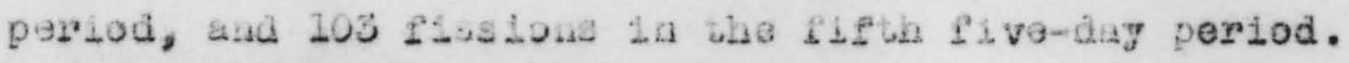
phere vas a towal difference of 250 fissions por tueaty-110 daya This tablo shows that the diforpaco his fission rate 10 favor of the outrol bet wat wot ghteat at

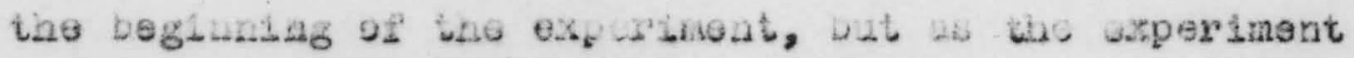
progreased, tho disobon zate decreased, ohosing a large differouge ta the fidston rate gt the tog sets. kigure of to a polygun onowing the arerage fissioa

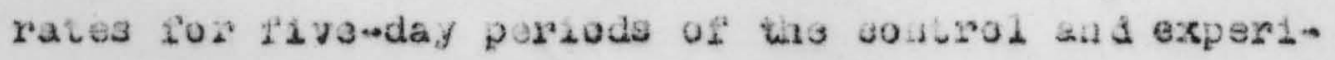

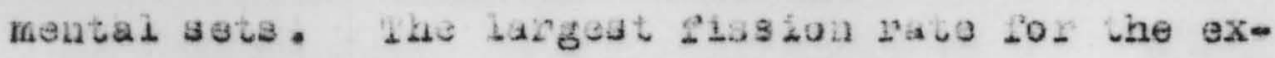

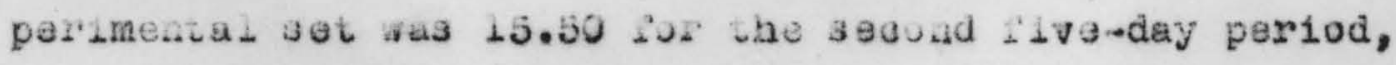

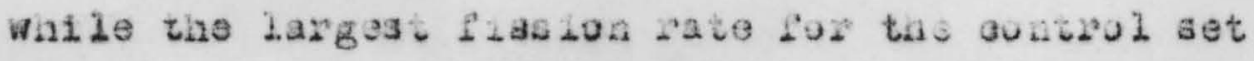
was 28.25 for the fifti five-day pexiud. Figure 4 is a polygoa showiag the five-day dif- 


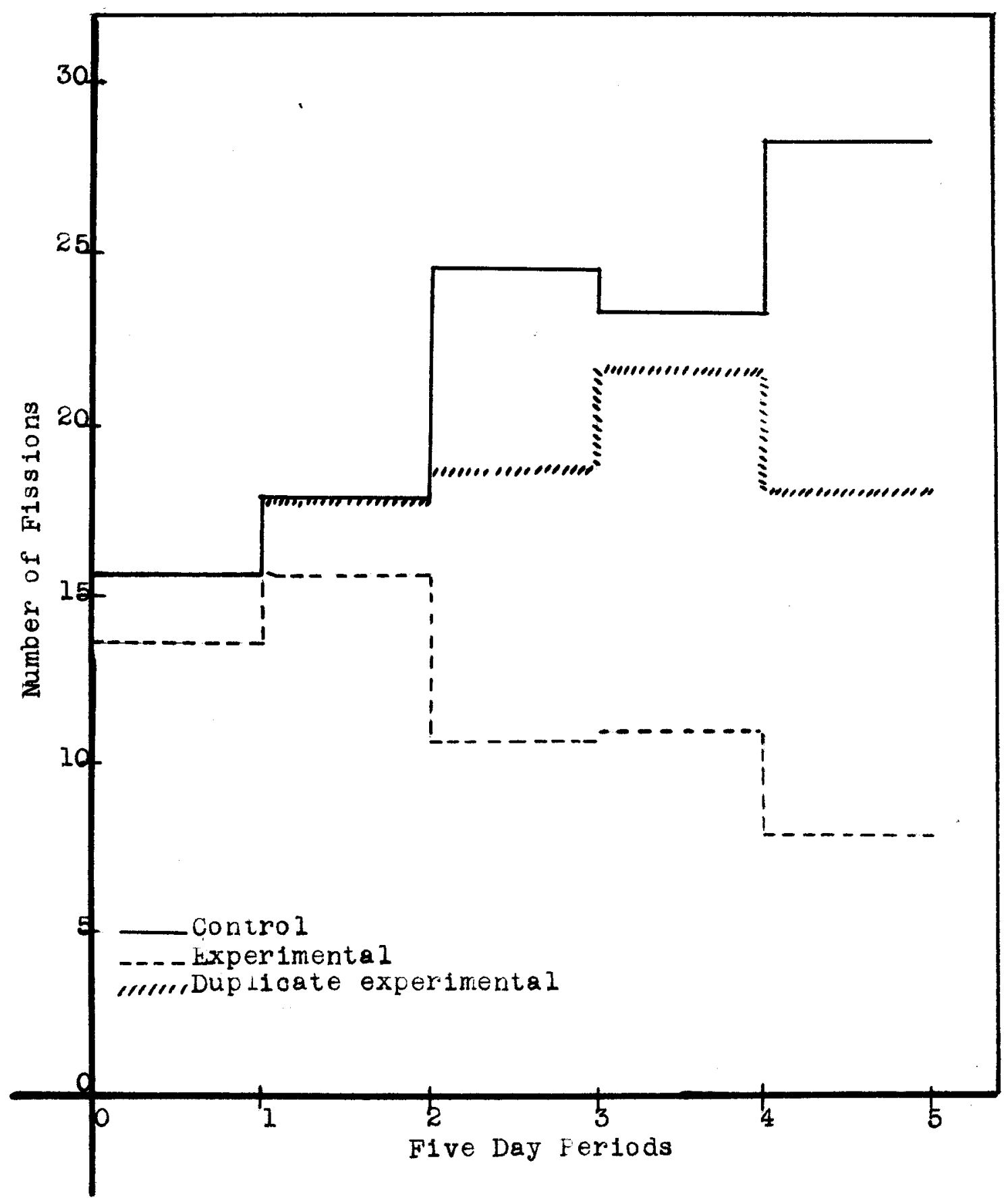

Figure 3. Polygon showing the average number of fissions for five day periods. 


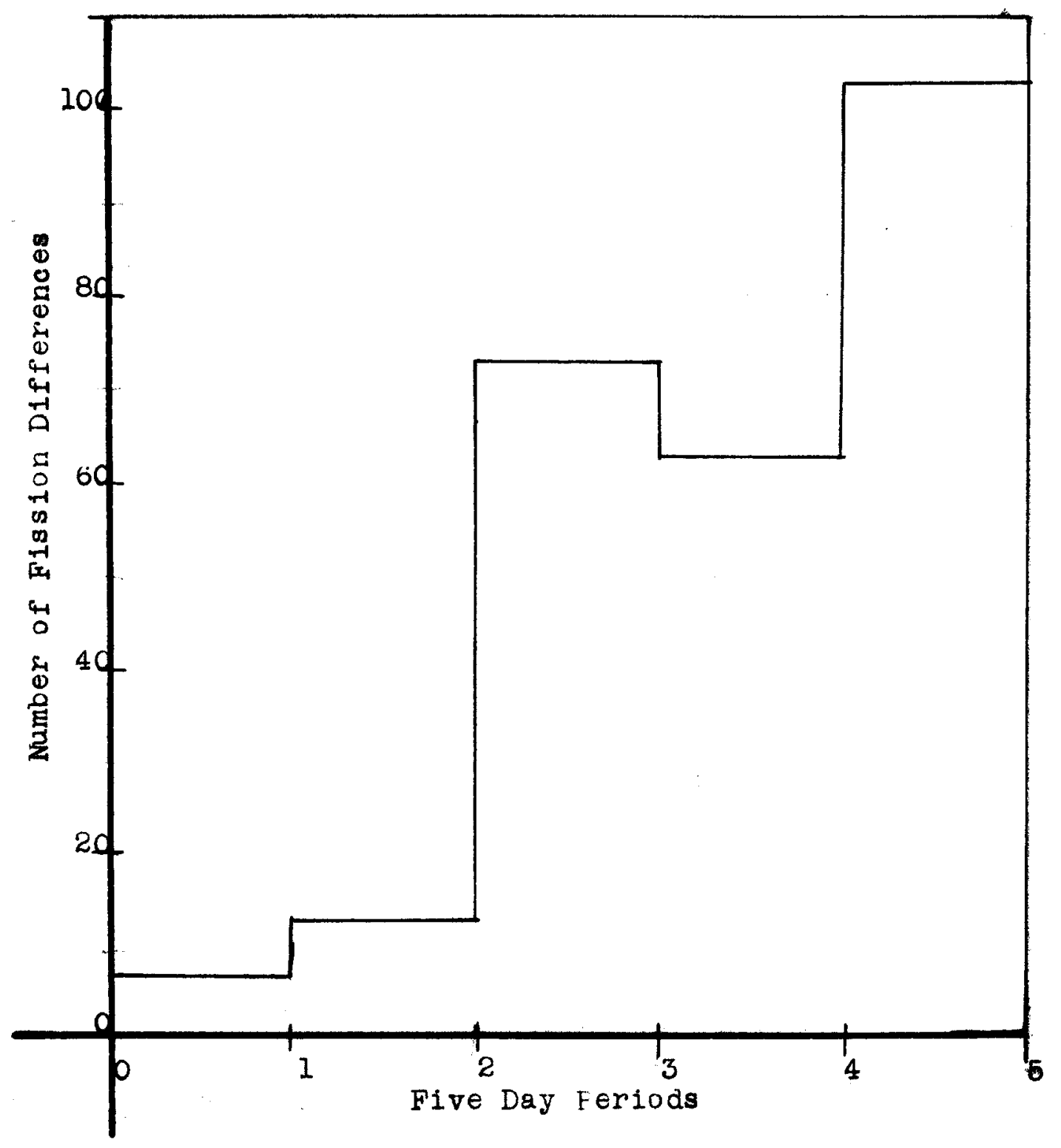

Figure 4. Polygon showing the five-day differences in fission between the control and experimental lines of faramecium caudatum.

Excess favors control lines. 
ferences in flssion rate betwoen the control and experinentej sete for rivo-dsy periods. The rizsion rate is in favor of the oontrol set. The fission afference Auring the flrat poriod ves 7, the socund period 13, the third period 73 , the fourth feriod 63 , and the fifth period 103. The result for Figure 4 wase given on trable $\varepsilon$.

Tabie 3 show the averaga da.12y $1.3810 \mathrm{a}$ in the coatrol and experimental sets for a period of twentyPive days. The differense between the avoregea in the fisston rate of the tro seta, 13 in favor of the control set. On the third, foumth, and serenth days, the fisaion rate of the axpertineatai act averaged more than that of the control. The respedive differences on these three days are $0.25,0.10$, and 0.85 f1ssions in favor of the experimeatal aet. On the remelning tronty-two days, the averagea dally risstoin rate of the control sot wh in exceas of thet of the experimentai set. Figure 5 shows olearly the ourve of the daily differenees between the everage number of fissions proAuecd by the control and oxperimental gets. pigure 5 supplomsats Iabie 3 . The arve designtiag the daily difforeages ia fiasion pat in favor of the gontrol get, ingreased stead1ly upand as tho pertod progresaed. 
Table 3

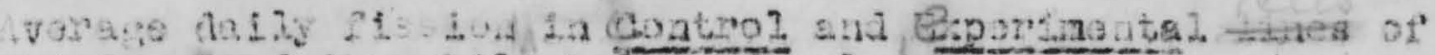

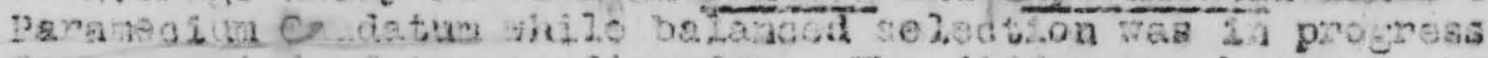

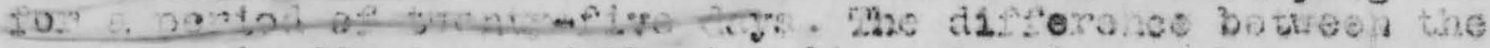

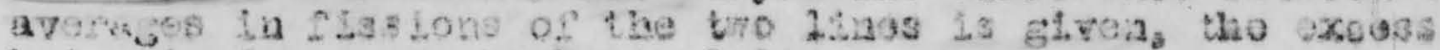
bej.ng in favor of the Gontroi. Iine.

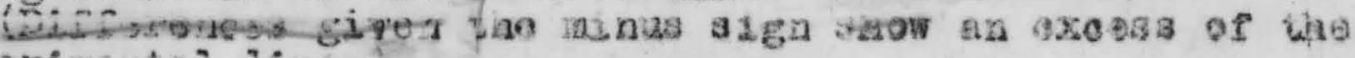

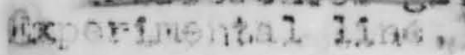

\begin{tabular}{|c|c|c|c|c|c|c|c|c|c|}
\hline Namber: of eeys & 2. & 2 & 3 & 4 & 5 & 6 & 7 & 3 & 8 \\
\hline AVOrEg CI8520nS & & & & & & & & & \\
\hline Cont22: & 0 & 2.25 & .80 & .90 & .95 & .76 & .60 & 2.20 & .75 \\
\hline ixpon & 0 & .80 & 3.05 & 2.00 &, 60 & .55 & .85 & .95 & .60 \\
\hline Difference & 0 & .35 & $=.25$ &. .10 & .35 & .20 &,- 25 & .85 & .25 \\
\hline
\end{tabular}

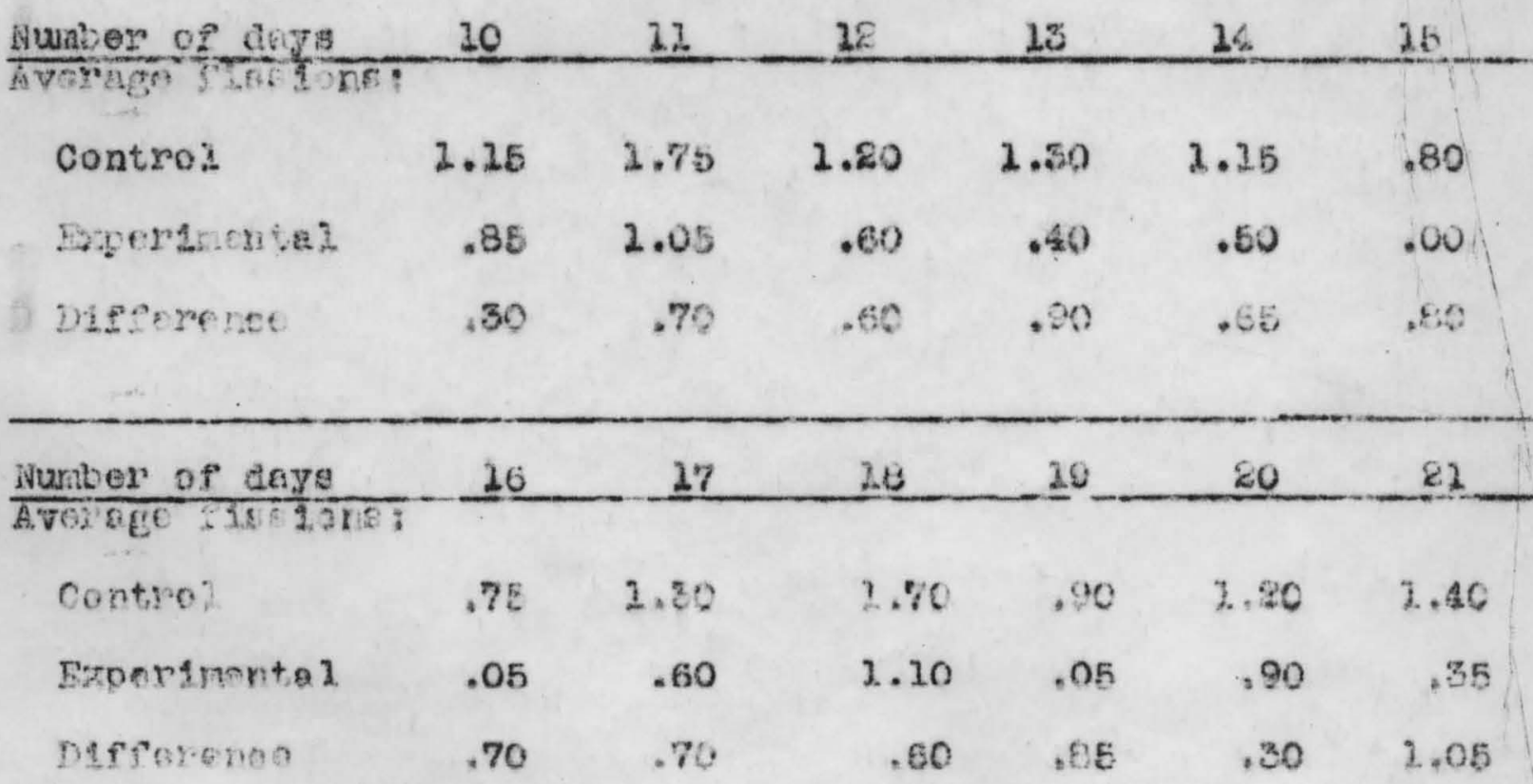

Bur bay of dify

Averafe the fons:

\begin{tabular}{|c|c|c|c|}
\hline contros & 3.25 & 2.05 & 2.55 \\
\hline zroptsile at 1 & .32 & .20 & 205 \\
\hline 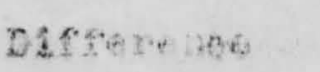 & .30 & .85 & 2.50 \\
\hline
\end{tabular}




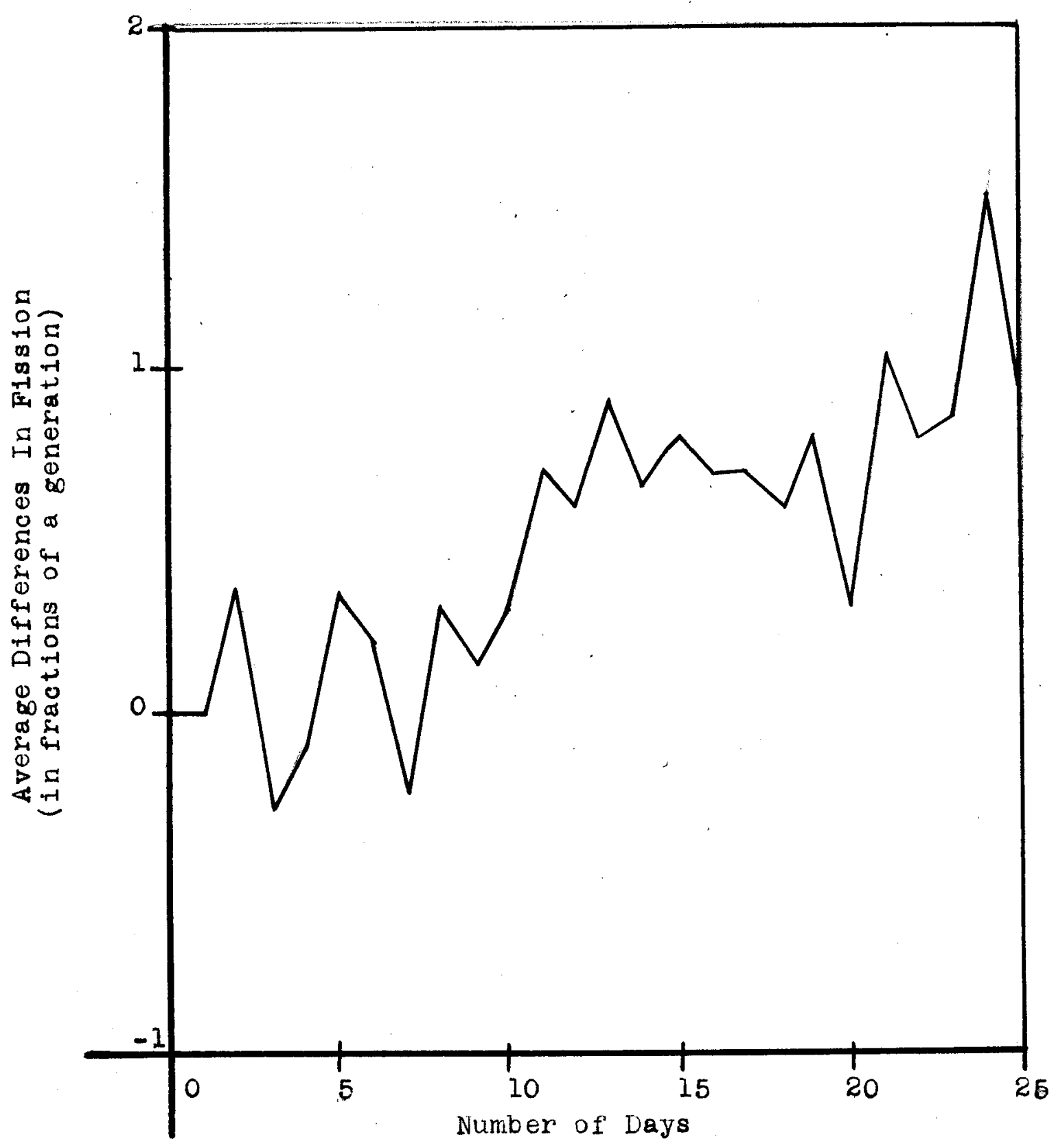

Figure 5. Showing curve of the daily differences between the average number of $\mathrm{f}$ issions produced by the control and experimental Iines.

Hxcess is in favor of control lines. 
Thble 4 hons the distijution of the netuel number of frocon por fromdey rersod for tha twenty Linse of the cortrol and exporamentsl sets. Tho

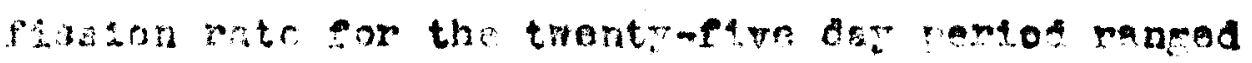
exom to 6.8 for the cortrol set. tho totel ris. stor rate vas 104.74, The fisstor netr for the narie forlod ranged Inon 1.8 to a for the exporimental

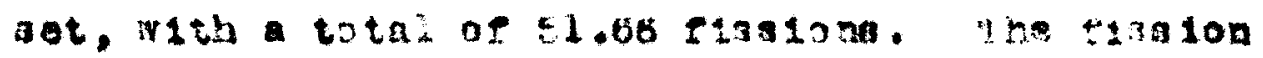
range for the twouty lines la the sortmol set was above the cledion range of the experimental sat. The two sets overlapted at 4 flea $13 \mathrm{~ms}$. She iarget fie- ion rate 25 the experimental ast was fisision,

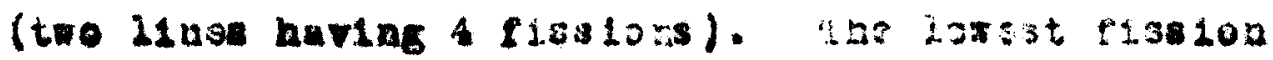
rate in the control sot was 4 risaiont, foro lino having (18: 10xa).

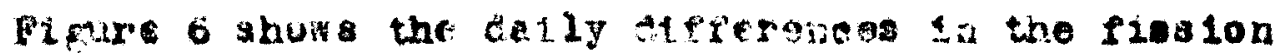

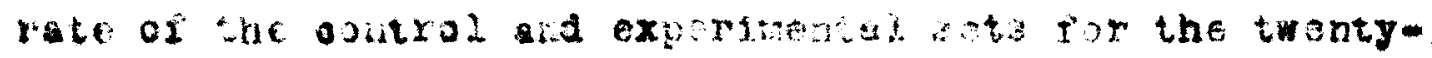

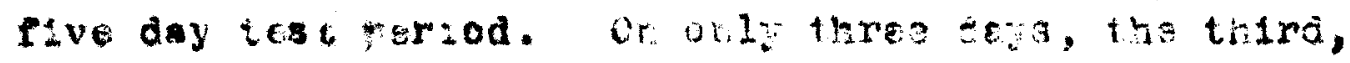

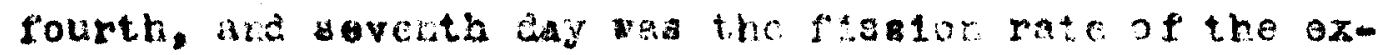

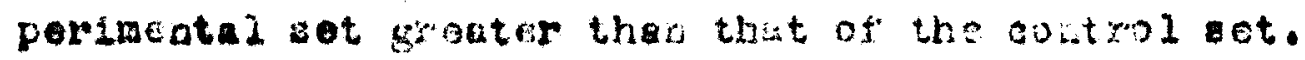

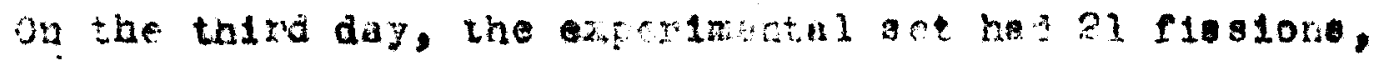

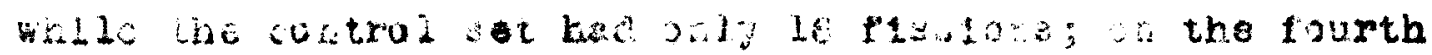

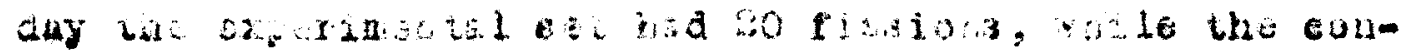
trob sot lud Gily 18 Piselona; and on the soverth day 


\section{Table 6}

Distribution of l1nes, al regard averege tumber of fias lon in the control and axperfimental 2inte duriag the terenty-pive day toet period. The fissiotu are averaged for fivemets periods.

\begin{tabular}{|c|c|c|c|c|c|c|c|c|}
\hline 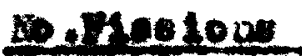 & .8 & 8 & 2. & 8.4 & e.6. & 2.0 & $\mathbf{s}$ & 3.8 \\
\hline $\begin{array}{l}\text { Conesol } \\
(\text { ito. } 21000)\end{array}$ & & & & & & & & \\
\hline 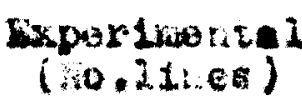 & 4 & $\boldsymbol{Z}$ & 2 & 2 & 8 & $E$ & 8 & Q \\
\hline
\end{tabular}

\begin{tabular}{|c|c|c|c|c|c|c|c|c|}
\hline borkespon & 3.4 & 3.6 & 1 & s.t & 4.6 & 4.8 & 5 & s.t \\
\hline$(w .21000)$ & & & 2 & 8 & 2 & 8 & 8 & 8 \\
\hline (Wo.21neal & 2 & 8 & $\varepsilon$ & & & & & \\
\hline
\end{tabular}

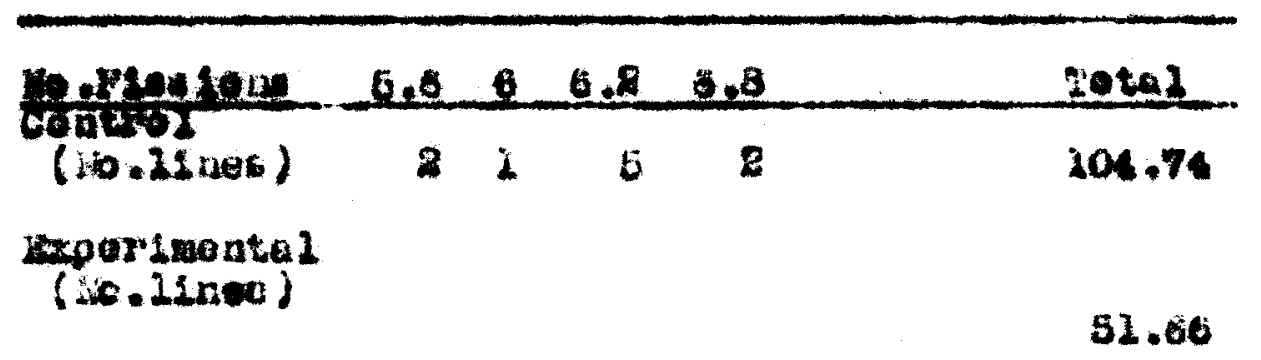




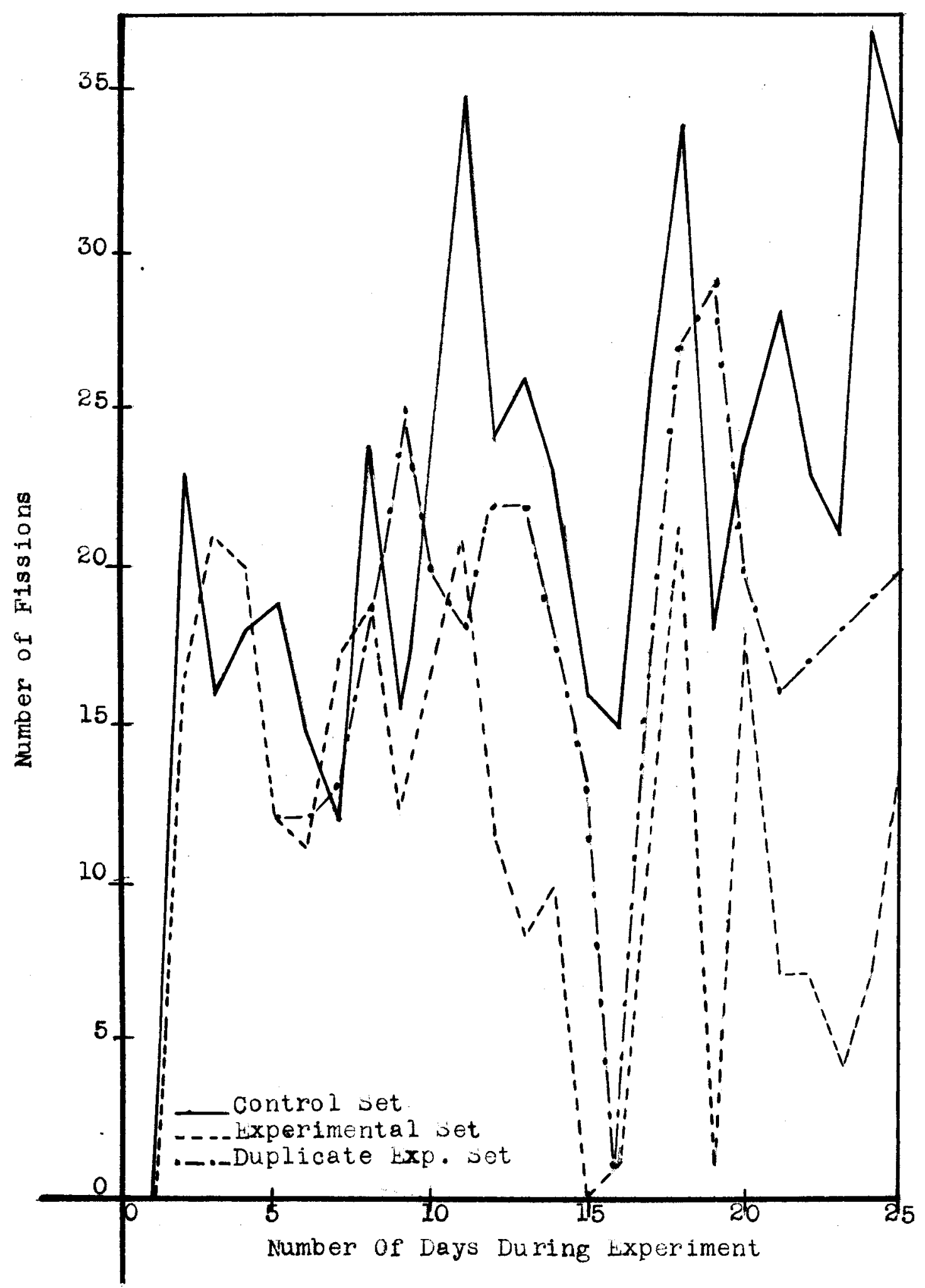

Figure 6. Curves showing daily fission rates in the control, experimental, and duplicate experimental sets. 
the experineintal set nad $17+3010 \times 3$, while the cortol sut had ondy 26 fistone. "irare nas a

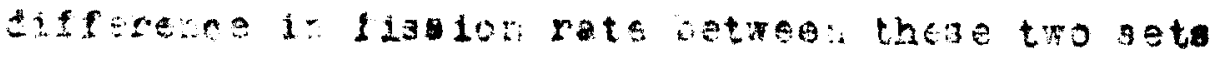

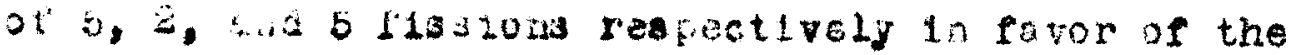
oxecrisintal at. On the remsialng trenty-two daye,

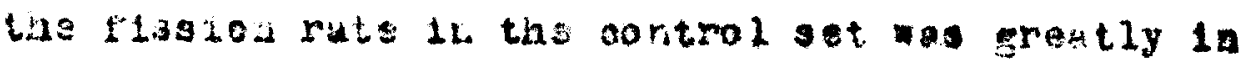
exoous of thet of the experimaintal aet. For the furst tea ady of tho test, the difforerge in fieston rate fo: tho two seta was not so not109able as it wus for the noxt fifteon days. Ihere was as ateady ab Lavease 2 in the riselon rate of the control vet as thers a decresse in the riscion rate of tho exparimotidi wet. Ihe figure hows a great divergeneo In the ines whioh represent the dally fiselon rate of the two seto. in the twenty-pifth day, the pis- Ion rate was 35 flacloum for the control get and 14 flaklone for the experimental wet.

Figure 7 stowe the rariution in arerage five-day pisalon of the control and experimental line during the trenti-fite day toot poriod. Ihis rleure

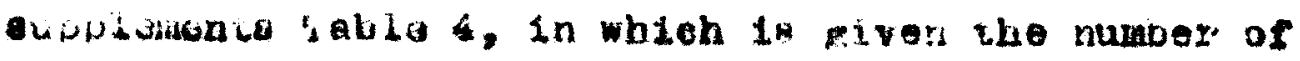
Liats wh their five-day fiation arerages. Ihio

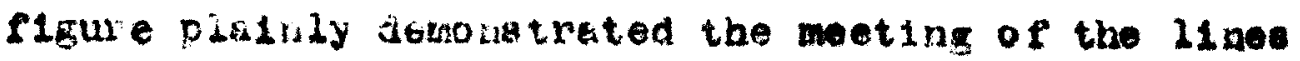




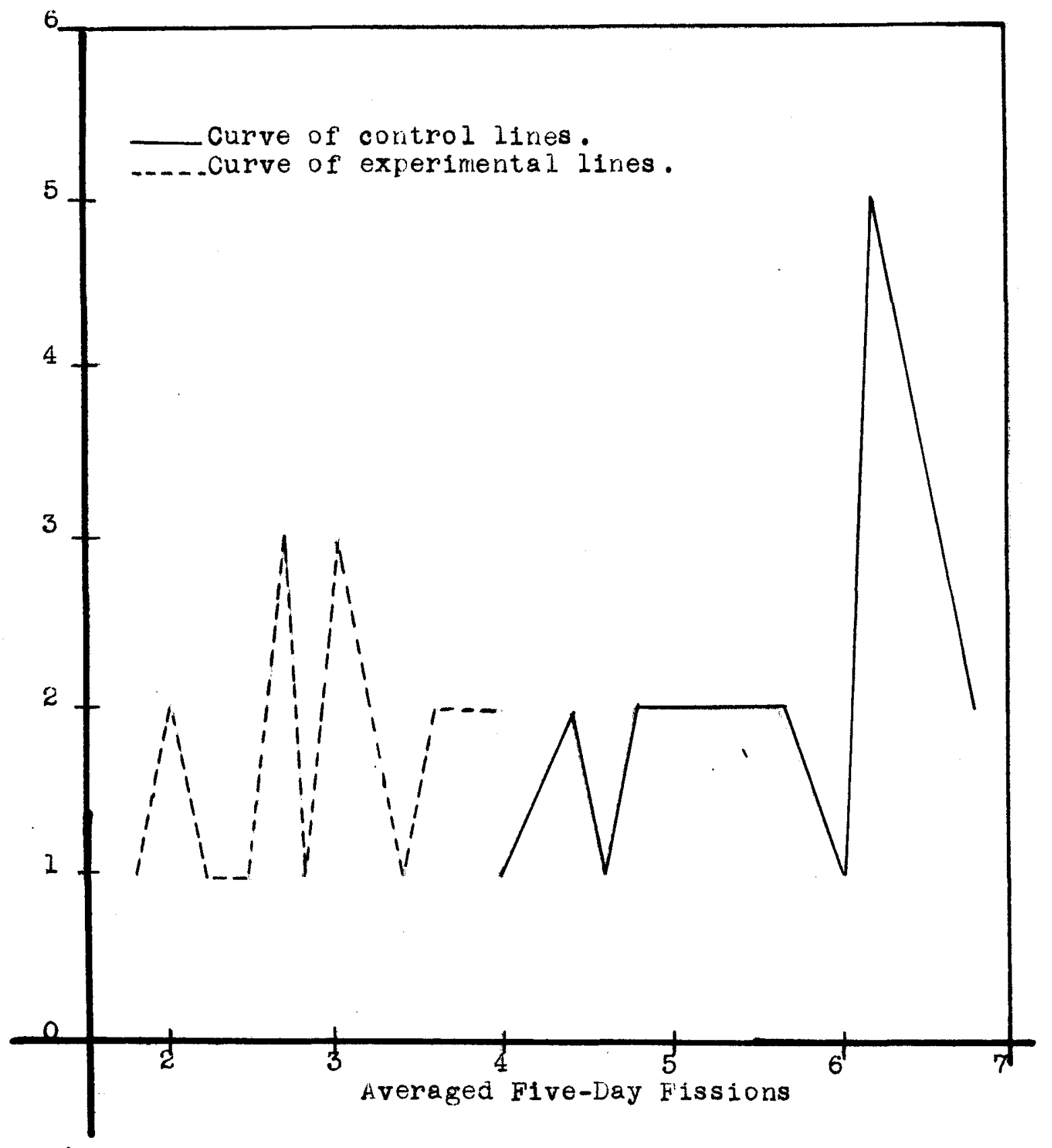

Figure 7. Curve showing the average fission rate for five-day periods in the control and experimental lines during the twenty-five day test period. 


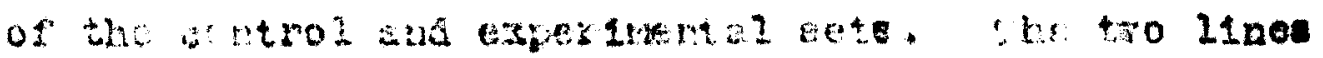

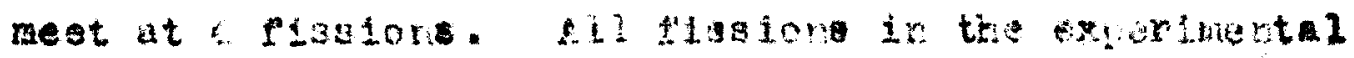

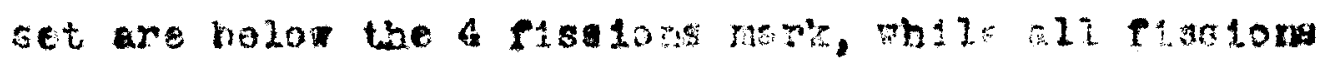

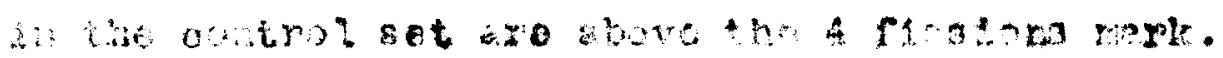

\section{Lines}

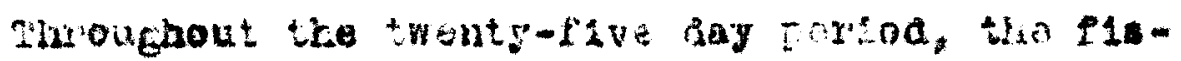

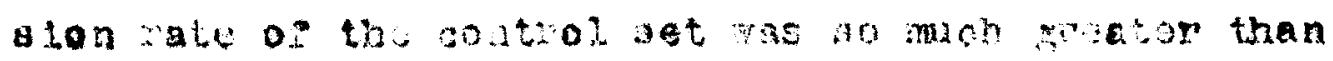
that of the exporibental at, that acteral faportant

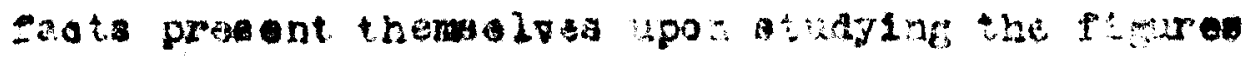
pertalatue to the two sata. Fyrat-mht the oodium

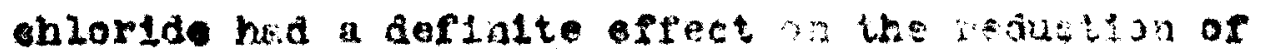

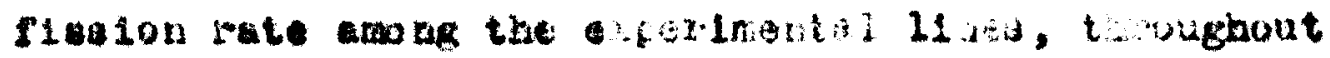
the perlod. Seoond-that the retuceit frolon rate

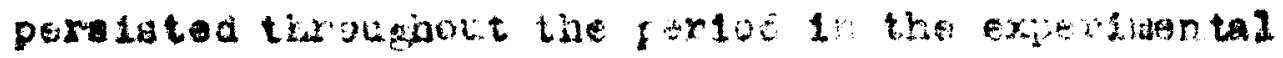
$s t$ 
BXPERIMENT II 
EXFGiIbibir II

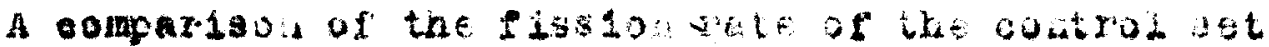
with that of the Dupllate exferlinental oet for a tireaty-day test period.

(Bopt. 30--0ot. 18, 1951)

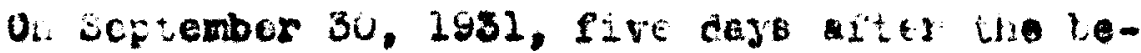
glnaing of the experiment between the control and experimental sote were otarted, the oxperinotid 21 nes were duplicated. A dingle paramectum srom each of the twenty 11nes in tho oxperimontal not was isolated In eab of twenty correspondingly numbered ground-

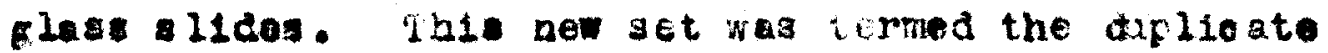
experimental sot. 2he paramecia la thie sot rere

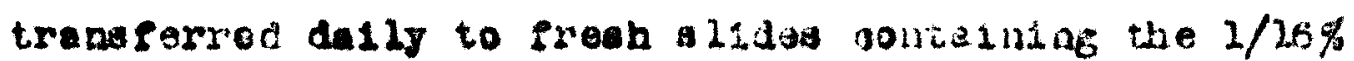
malted milk oulture medium, The parainedia tis the experimantal sot were traneferrod dally to frog $321 \mathrm{des}$ containinf: the sodium onloride calture medinn, The three sets wore Li progres at the gane thre for a perlod of imbow days. All condtions as cenperative, lieht, bacterial content, end cleanlicess, wore uniformIy malntained for the three sets.

Plgure 5 (ate page26) 1. a plygo, of the flasion

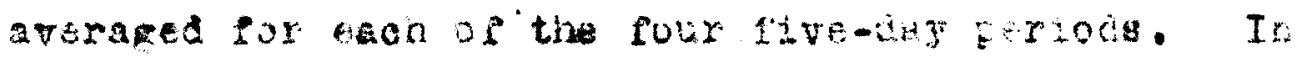
the cortrol set, there was a dally averse ot 17.75 fig-

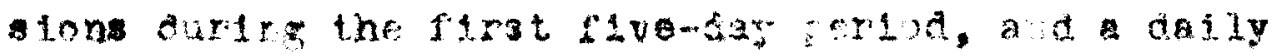




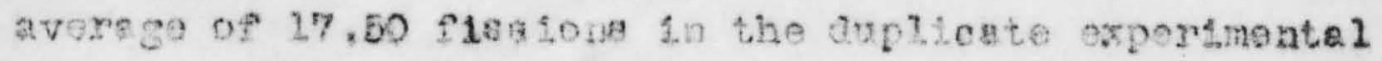
sot, loaving a desiy drfference of 26 fisaton during the furst efvemeay portod in favor of the controi sot. During tho somond flve-tay perioe, there was an avorage da $13 y$ ftsaion rate of 24.60 fissions an the oontrol sot, and 19.50 fissions in the enplsgete exportnental.

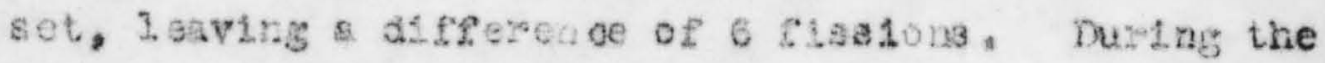
third etve-day period, thero vas an average cally ris. s10n rate of 23.25 frastons in the control set, and 21.50 flssions in the tuplioate 6xperkmontal set, leav1ng is datly differenso of 2 finotons. The fourth fivec.s.y pertod showis an average ta1.1y rission seto of

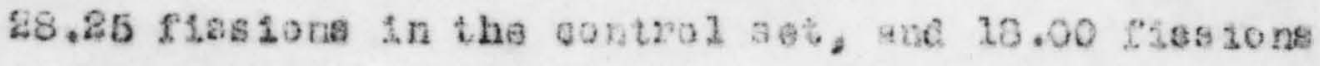
Sn the diplieate experinetal set, leaving a delig difrerenee of 10.25 flasion, There was a mured differcnee in fise 100 rate betrees the oontrod and experinetital asts furlag wach of the four fivo-day periods. The rate of fission in the oontrol aet Inoressed as the poriod lenethoned.

5igure 8 is a poiggon shoviag the flvondsy sisston difrerenees between the cotrol and duplicate experingatsi linos. 421 fiasion dipferenes for the fous sivenday perlods favo: the oontrol set. During 


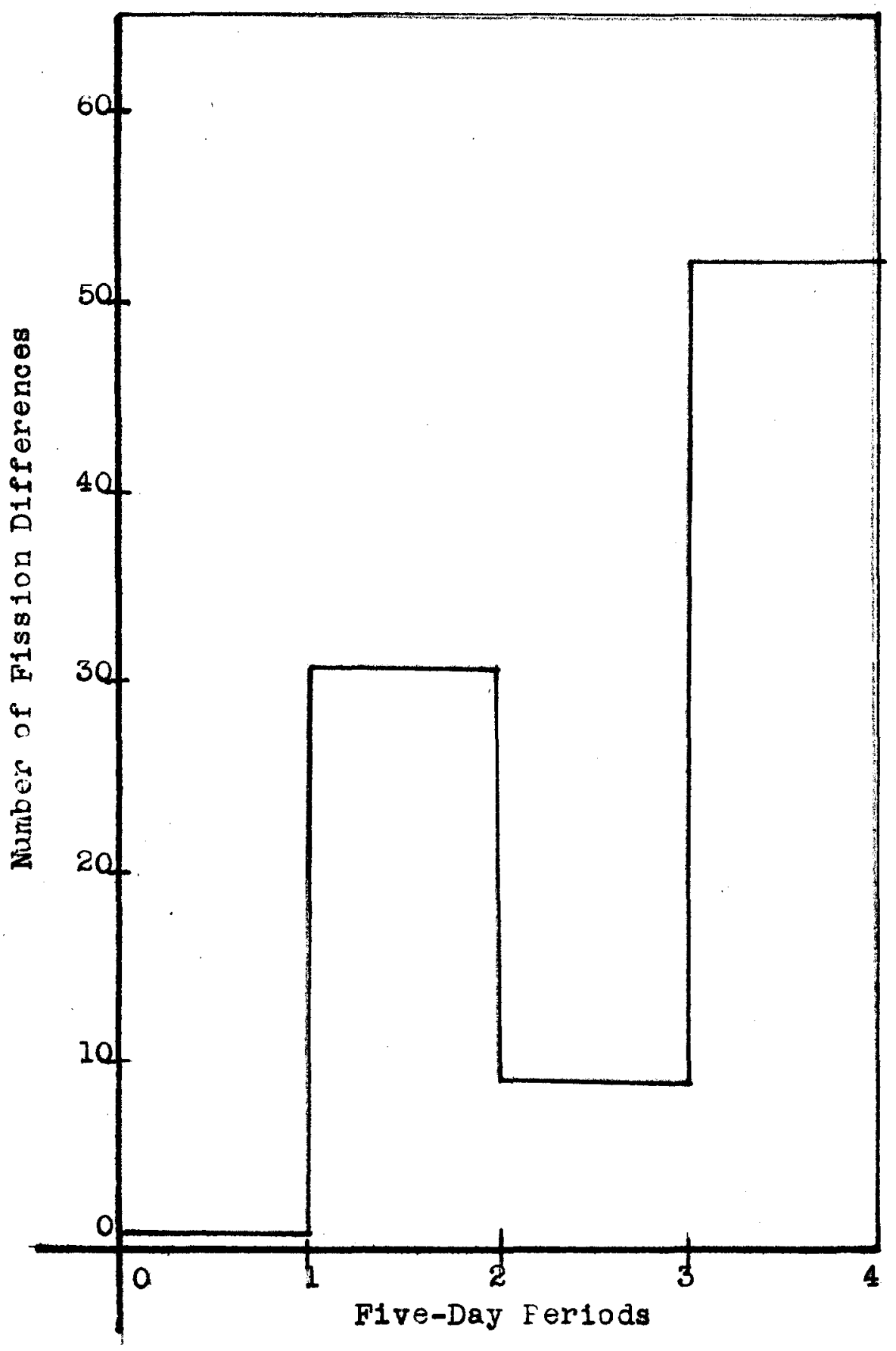

Figure 8. Polygon showing the fiveday fission differences between the control and duplicate experimental lines.

Excess favors control lines. 


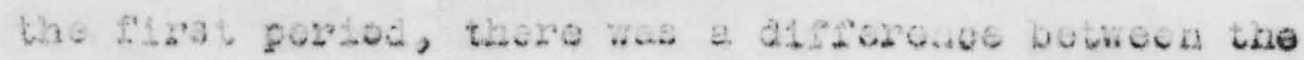
two sets of I plestor. In the sooch portod, ibero

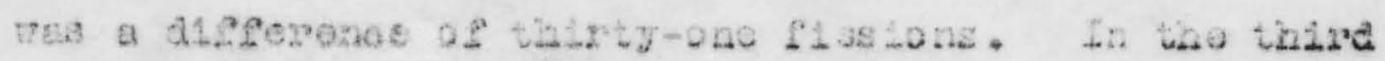

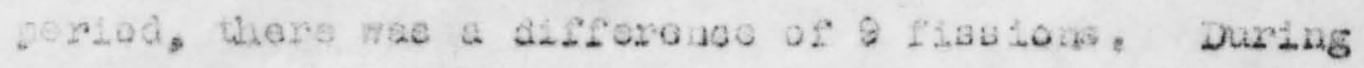
the fourth fivandey poriod, thore was a difforouce of

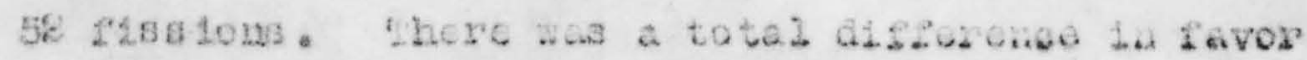
Of the oontiol set fur the ontiro thowty days of os

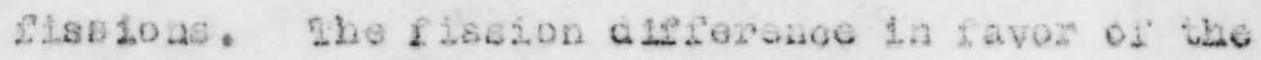
goatrol set was getetet during the last fiverday

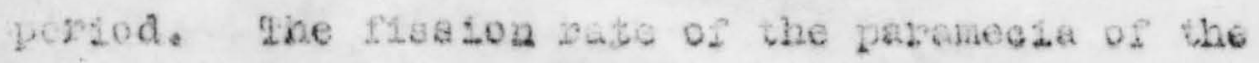

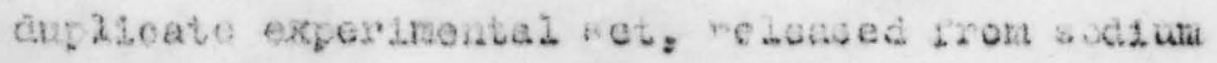

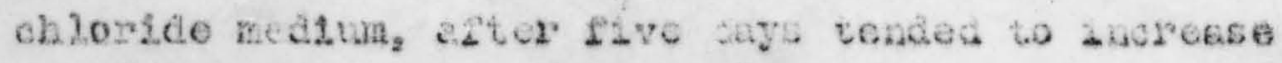

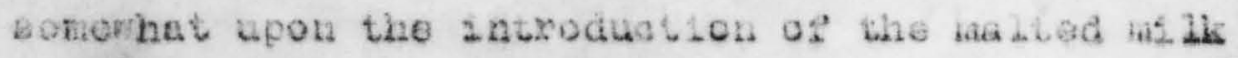
culture medtua.

Rigure $\theta$ ahows the dahly dirforenoce botweos the sverege nunoer of fies lous produced by the coutrol. ana duplieate experimental sots for a pollod of tronty days. The rass 100 differoncez for the twaty days are us follows: flrat dey, tho ilsstons la fuvon of the outrod sot; securd day; .OB fise1on fin favor of

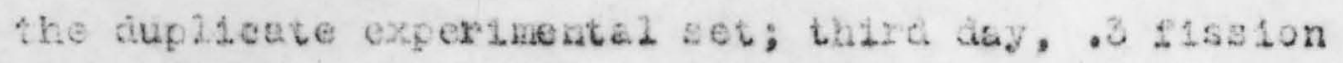
In favor of the oontrol aet; fourth day, of fassion

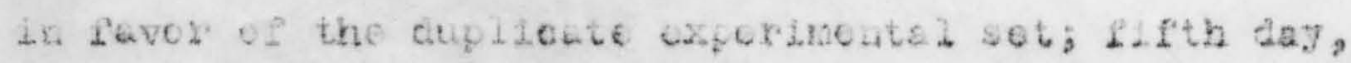
.26 fluspon in favor of tho control det; sixth day, 


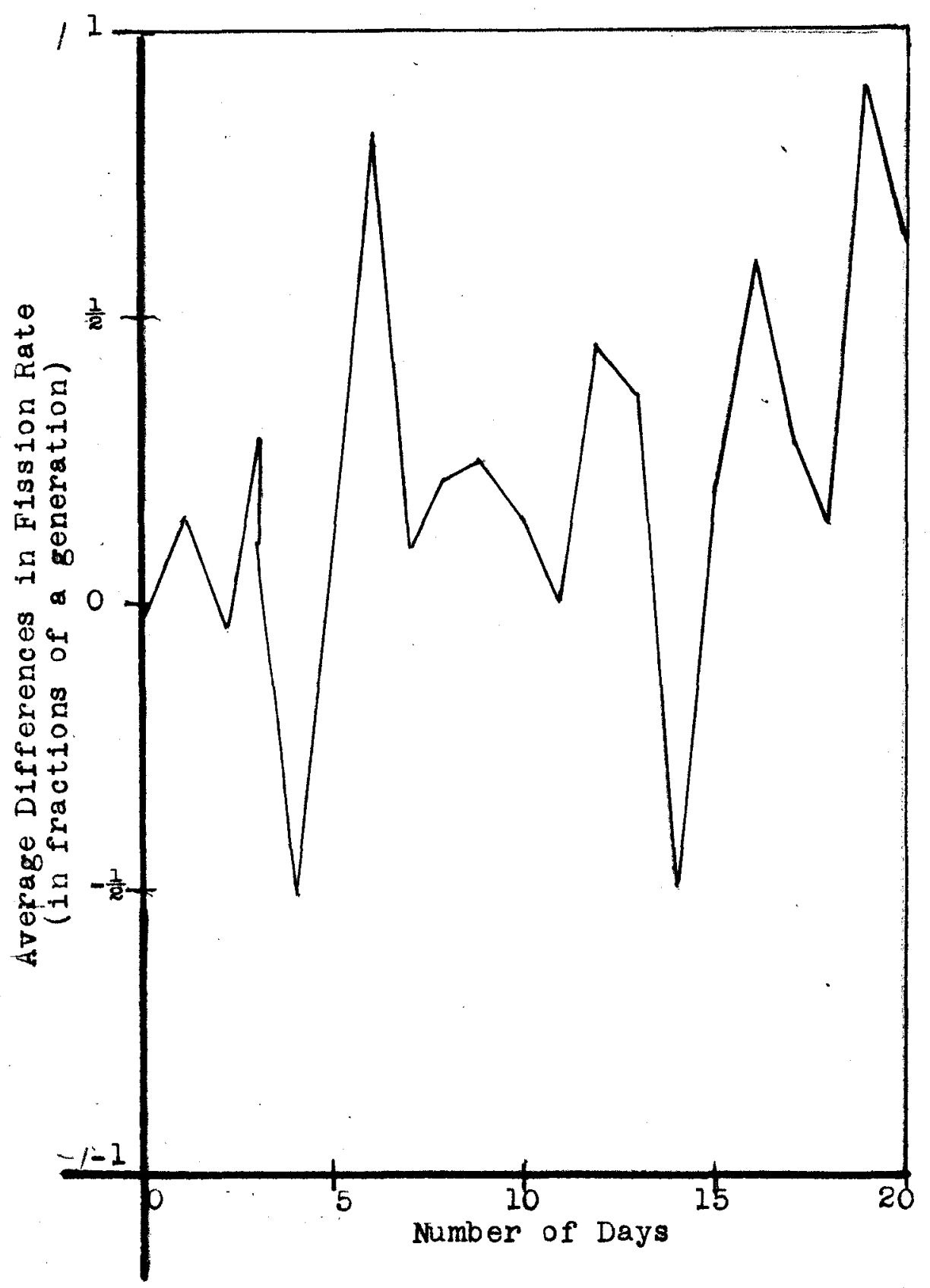

Figure 9. Showing the curve of daily differences between the average number of the fissions produced by the control and experimental lines.

Excess in fission rate is in favor of the control lines. 
.85 f18e10n in faror of the cortrol oet; oeventh day, .2 fission in favor of tho control set; elghth day. .8 flsaton in favor of the control set; ninth day. .25 fision 10 fuvor of the controd set; terth dag. .25 fiesion in faror of the controd sot; elerenth day, fiselon rate was equal, twelfth day, 46 fle- Ion in ravor of the ootrol sat, thirteonth day, .35 ries1on in favor of the contrel set, fourteenth day, .80 fisalon in favor of the duplicate exper1mentel set, fifteenth day, 2 r1sa10n in favor of the ooptrol cet; sxteenth day, .6 fission 1u faror of the eortrol sot, cerenteonth day,. 8 flesion in ravor of the coutrol set; elghteenth day, .26 I1sa10a in favor of the oontrol aet, alnoteonth day, of fasion In faror of the oontrod ats and trentieth day. .65 Fission in favor of the control set. On oaly the weoond, fourth, and fourteonth day dit the arerago daliz fiselon rate of the cupileate experinerital set expeed that of the control set.

Iable (see page 44) givea the distribution of the twenty lines a regards notual number of fiss low in the cortrol and duplioate experimental ots for the twenty-day teat period. Ihe figlon were talket per five day period. The range for the twenty lives 
Teble 5

D1.s Lxibution of lines, as regards average nuber of fl.ssiona in the control and duplisate exporimontal 11 neg during the twenty-dey test perise.

the fissiong are areraged for five-day perioda.

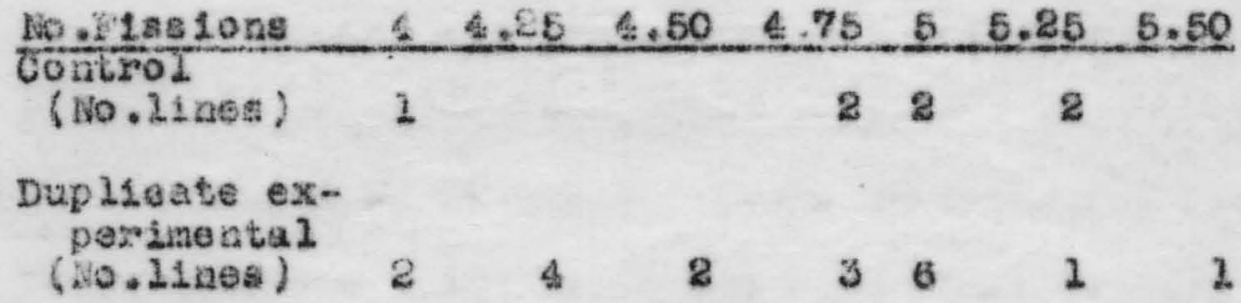

\begin{tabular}{|c|c|c|c|c|c|c|c|}
\hline No.P1ssions & 5.75 & 6 & 6.85 & 6.50 & 6.75 & 7 & 7.25 \\
\hline $\begin{array}{l}\text { (No. } 1 \text { ines) } \\
\text { (No.2 }\end{array}$ & 1 & 5 & 2 & 2 & 2 & 2 & \\
\hline $\begin{array}{c}\text { Duplicate ex- } \\
\text { erimentaz } \\
\text { (io.j1nos) }\end{array}$ & 2 & & & & & & \\
\hline
\end{tabular}

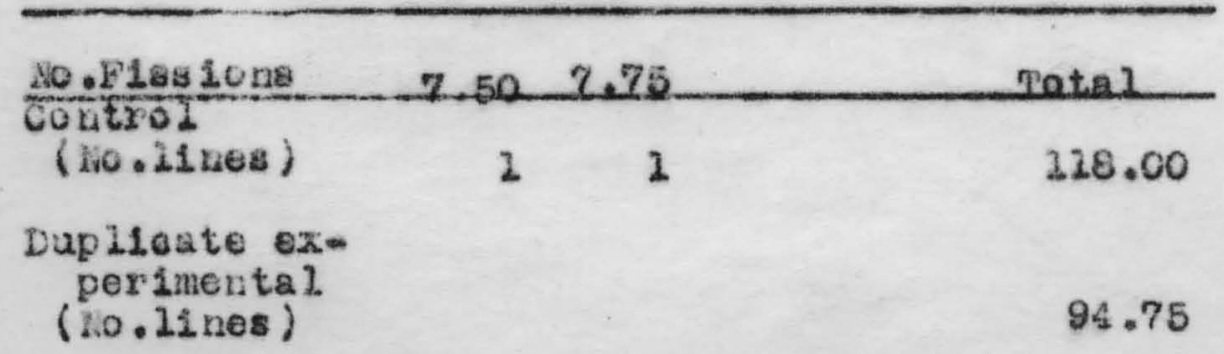


In the eontrol set was from 4 to 7.75 fision, with - total of 128.00 rienson for the twenty deys, one

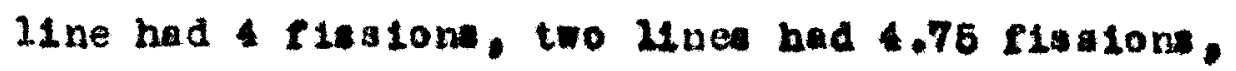

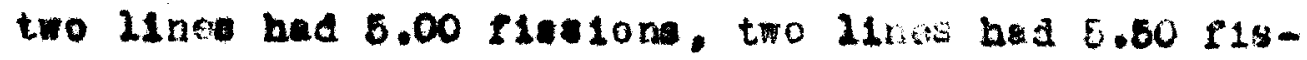

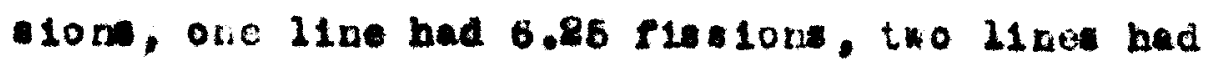

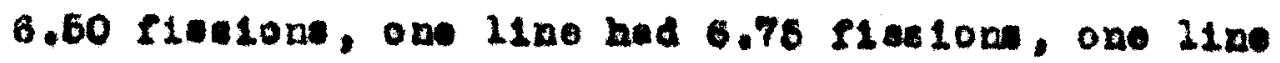

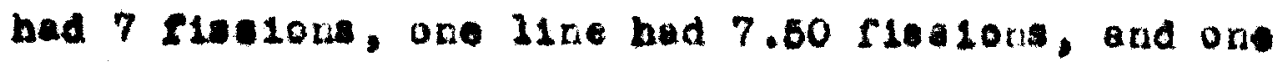
line had 7.76 flesters.

The range for the twenty 11 nes 1 in the duclleate experimentel set was from to 0.75 f1salone, two fisstone leat than that of the range for the control et. Iwo 2lace in the duplicate axperimentel ect

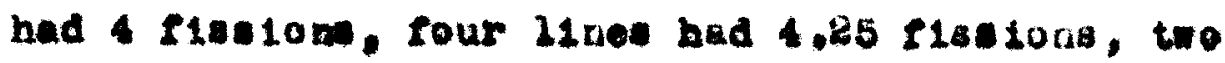
I1nee had 4.50 fiestom, three 21 nes had 4.75 fiseton,

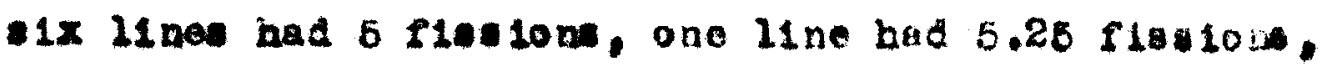
one line had 5.60 frenlone, and one 21 ne had 5.73 flas 10na, making total of 94.75 flarlong in the twenty 21 nee for the twenty days. The greateat number of fieston in the control set sell at $6 \mathrm{riH}-$ 10a, whilo the greatest number of rissions in the duplionte experimontal oot fell at 5 fiselon. She mean for the fisaloa rate 10 the oontrol sot foil at

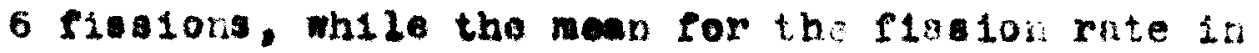
the duplloste exporimental set fell at 4.75 pissions, 


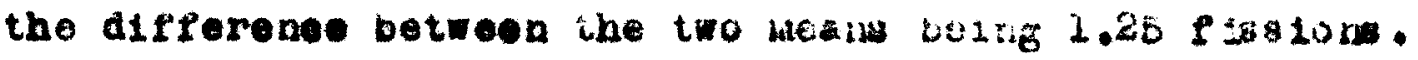

F1gure 6 (eve page 33) show the dally dilfereneen In the flesion rate of the oontrol and the cuplioate

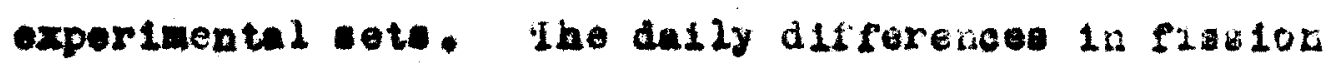
rate between the two cecs ax w tellows firat day, 7 flesiow ravoring the controd cet; ocoond ay, I f1ea lon favoring the duplieate experimerital set, third cay, - rieslon favoring the control set; fourth day, 10 f1selone faroring the duplleate experimental set; fifth dej, s flesione favoring the cottrol set; sixth day, 27 fiselone faroring the eontrol eot, seventh din, 2 flesione favoring the control sot; Olghth day, Ife-

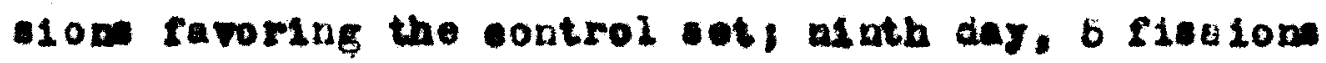
faroring the controi oet; tenth ary, 3 fisalons fayorlag tho eontroi sets eleveath day, flessoco were equals twolfth day. Slasione favoring tho ountrol oot, tbirteenth day, 7 fled lone favorlag the cutrol bet; fourteonth day, 11 flas lon favorilig tio dizlleate gxperimental ot, fifteonth an, fleslone favoring the control sot; sixteenth day, IE flo slows faroring tine control aot; seventeenth day, 6 flsalon favoring tho control set; e1phtoenth day, 3 fladous favoring the

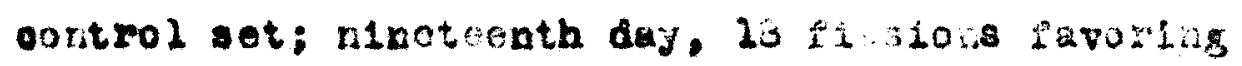
the outrol set; and twentieth a d is flalons fevoring the curtrol set. The total differenes of pleston in 
favor of the eontrol ot for wa tast perior mas 226 f18310m, wh120 in tho dupl10ate experinente 2

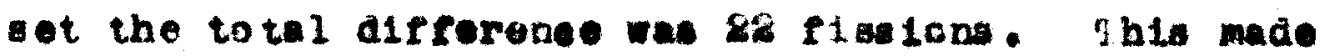
a rivaion differanoe for the onitre porios of 103 fise 10ne in faror of the nontrol sot.

Mgure 20 how the variation in avorege 5 day Ission of the eotrol and duplisute experinental oote. Ihie rigure applenents iable 5 (eoo page 44 ). The line whioh reprecente the arerage flve-iay fles $10 \mathrm{n}$ In the duplieate oxporimentai aut hows the twonty ijnes within the fiecion range of 4 to 5.76 fisituno, whilo the 21 ve wbieh represente the average itre-day flaclon in the eontrol set abowa the twoaty lino hering the proater flsaion range of to 7.75 f129100\%.

lablo 7 nows the number of $f 1350$ is por flye-jay period per line in the control and duplieate oxs er1wental sots.

Durlag the elme elvo-iny ferlod, the twetg 11nes of the control cet wrormgea .06 1 18 along more than the tronty 21 new of the oontrol sot. Furd ct the seoond rive-dey period, the therty lins of the ooptrol set averaged 1.66 flo 10 ia mos than ald the duplicate experinental sel. I: the thisd ftre-day 


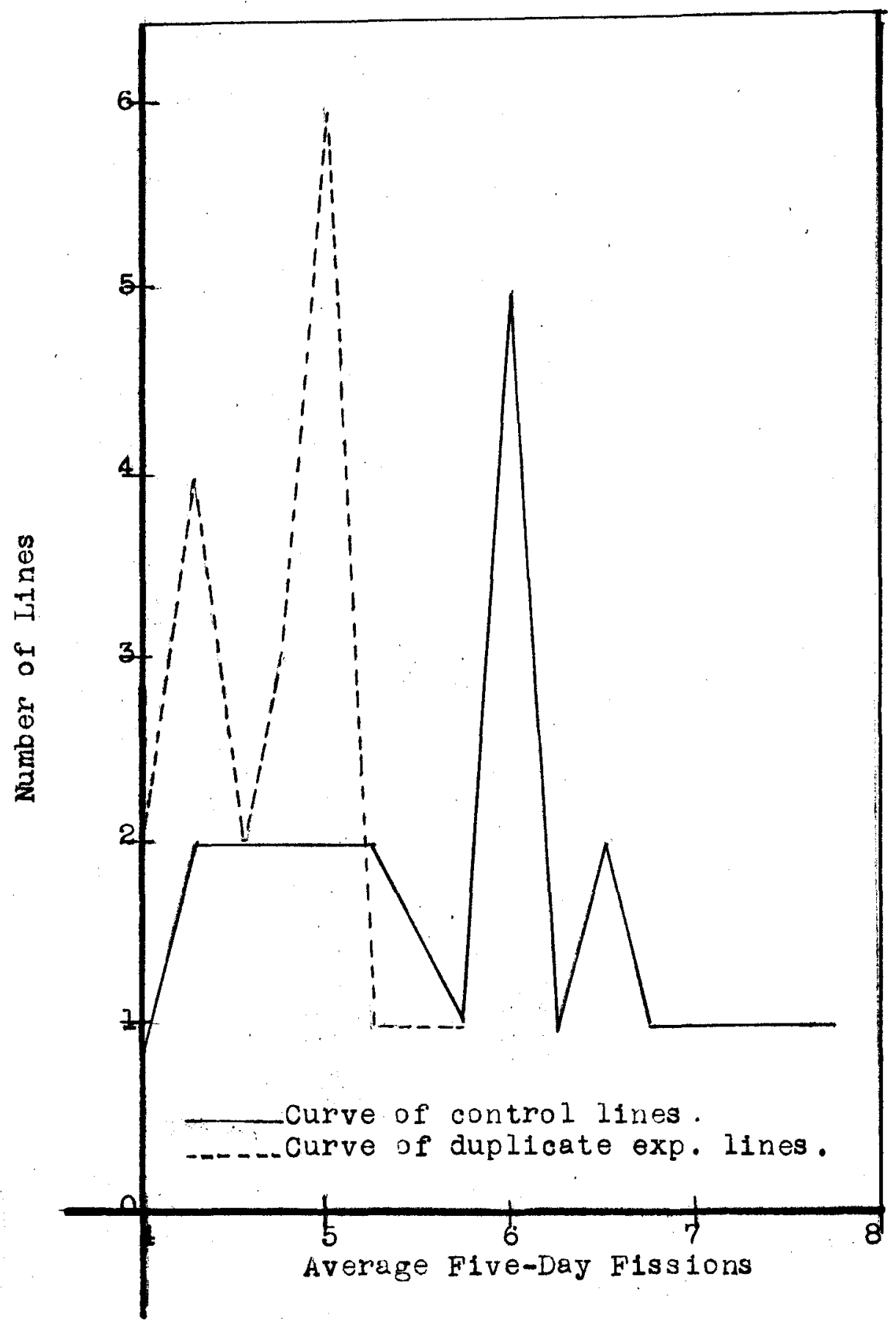

Figure 10. Curve showing the average fission rate for five-day periods in the duplicate experimental and control lines during the twentyday test period. 


\section{Table 7}

Aetual number of fissiona per tive-day peitod par line of the

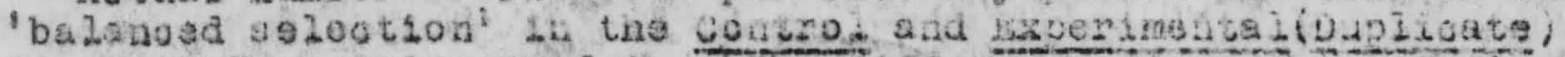

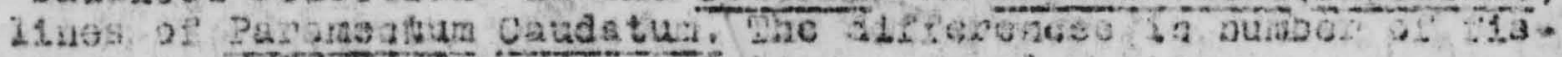

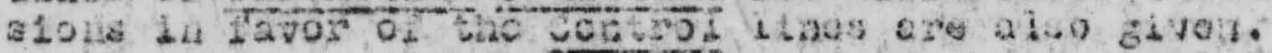

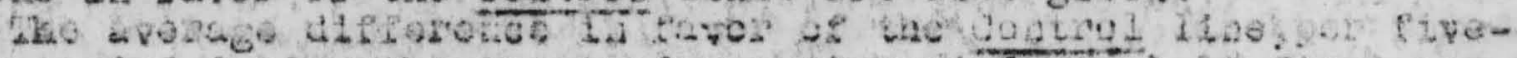

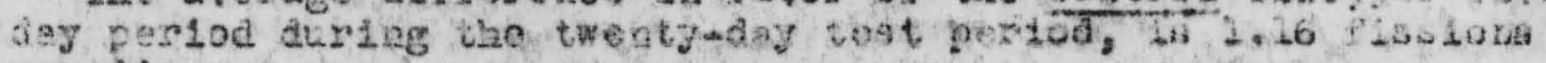
per line.

\begin{tabular}{|c|c|c|c|c|c|c|c|c|c|c|c|}
\hline I1aeg Number & 1 & 2 & 3 & 4 & 5 & 0 & 7 & 8 & 3 & 20 & 21 \\
\hline $\begin{array}{l}\text { First b-day period: } \\
\text { Control }\end{array}$ & 0 & 4 & 1 & 3 & 4 & 7 & E & $=$ & 2 & 5 & 7 \\
\hline Dup. Exporimental & 4 & 3 & 4 & 4 & 3 & 6 & 4 & 3 & 4 & 4 & 6 \\
\hline Difrerance & -4 & -1 & -3 & -1 & -1 & 2 & 2 & 2 & -3 & 3 & 2 \\
\hline
\end{tabular}

Second 5-day pardod: Cuntrod $\begin{array}{lllllllllll}6 & 6 & 6 & 7 & 2 & 5 & 7 & 7 & 2 & 5 & 7\end{array}$

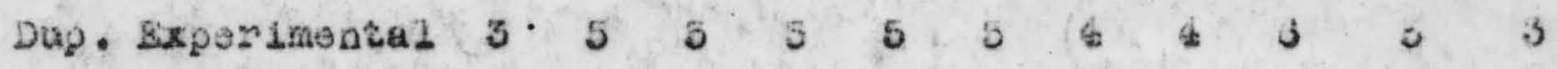
Mifferenos $\quad \begin{array}{lllllllllll}3 & 1 & 1 & 2 & -3 & 0 & 3 & 3 & -4 & 0 & 4\end{array}$

cinlra 5-ảay period? Control

$\begin{array}{lllllllllll}5 & 7 & 6 & 6 & 4 & 6 & 7 & 3 & 3 & 3 & 5\end{array}$

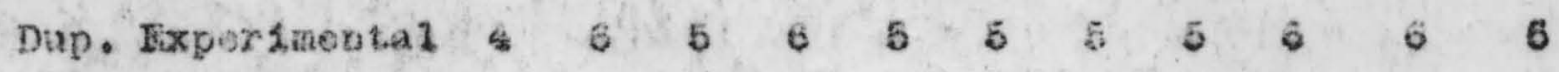
$\begin{array}{llllllllllll}\text { Difrarsus } & 2 & 1 & 2 & 0 & -1 & 1 & 2 & 3 & 2 & -3 & -1\end{array}$

Fourtin 5-day period: Control $\begin{array}{lllllllllll}8 & 7 & 8 & 8 & 6 & 5 & 8 & 5 & 3 & 7 & 5\end{array}$

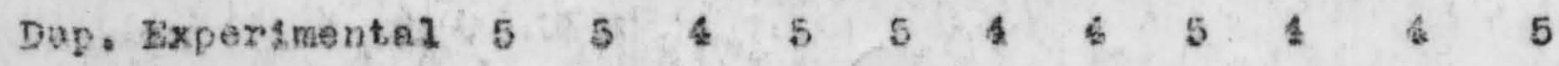
Difference 32432134243 
Table 7 .

In thie tazle, the numbers $1 \mathrm{~d}$ the 'diperences'

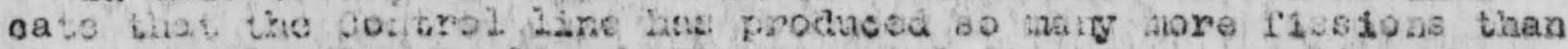

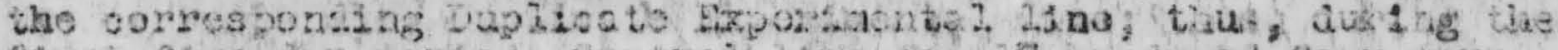

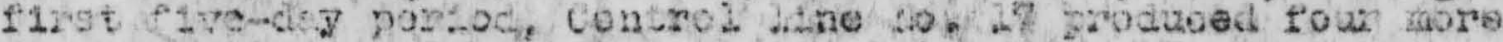

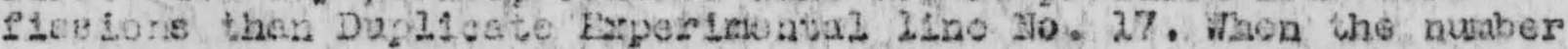

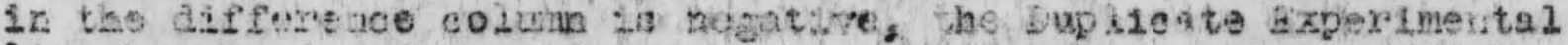

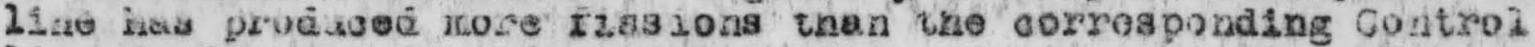

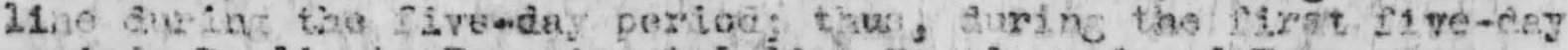
poitos, Tupilaste Experimental ins No. I prodused four moro fibe10ng tam corfesporeing control line Ho. I.

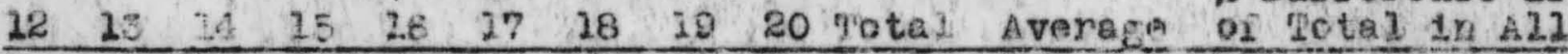

$\begin{array}{llllllllllll}3 & E & 4 & 5 & 5 & 7 & 5 & 5 & 6 & 89 & 4.45\end{array}$

$655843 \quad 3 \quad 5 \quad 5 \quad 98 \quad 1.40$

$00-1282 \leqslant 10212.05$

.01

$\begin{array}{llllllllllll}9 & 6 & B & 7 & 3 & 8 & 6 & 9 & 8 & 124 & 6.20\end{array}$

$\begin{array}{lllllllllll}7 & 5 & 4 & 4 & 5 & 4 & 4 & 7 & 3 & 90 & 4.65\end{array}$

$\begin{array}{lllllllllll}2 & 2 & 4 & 3 & -9 & 4 & 2 & 2 & 5 & 32 & 3.55\end{array}$

.14

$47 \quad$ 4 E E $6 \quad 5 \quad 6 \quad 7 \quad 117 \quad 5.85$

66 6 5 E E E 5 \& 308 5.

$\begin{array}{lllllllllll}-2 & 2 & 0 & 0 & 0 & 1 & 0 & 0 & 3 & 9 & .45\end{array}$

.04

$\begin{array}{llllllllllll}3 & 8 & 8 & 6 & 8 & 10 & 8 & 10 & 7 & 24 \% & 7.10\end{array}$

445 4. E 45 \& 5 90 4.50

$\begin{array}{llllllllllll}-3 & 4 & 5 & 8 & 3 & 6 & 3 & 6 & 2 & 52 & 2.60 & .22\end{array}$

$\begin{array}{lllllllllll}-3 & 6 & 6 & 7 & 2 & 10 & 6 & a & 12 & 93 & 4,6 t\end{array}$ 
period, there wa difforevoc or of fistion la furor of the ontrol set, making an average of 45 t1ssione for tho third period in favor of the soutrol aet. During the rourth five-day period, ths ouatrol ist produce 62 taton mole thris did the duplicate experimontal oet, so thet the coutrol at avoraged 2,60 fiesion more then did the dufileate exparingutal set.

Tho difforenes in fisalou thate tis favor of the control aot for the twonty days was os fissicns. Sao average differoneo in fleciun rate in favor of tino contrel sot for the twenty duye wae 4.86 f1selor.

\section{MLSULIS}

Inroughout the period, the ines in the cortrol

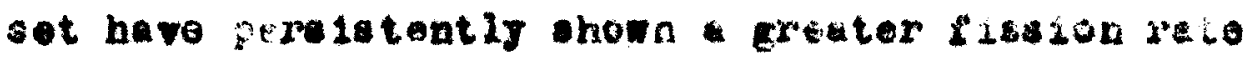
thar the lines in the duplleate oxperimertal set. Then the parameosa were staxtca in the cotrol at In the malted milk oulture dism, they tended to steadily inerease their risoion reto da tho prod

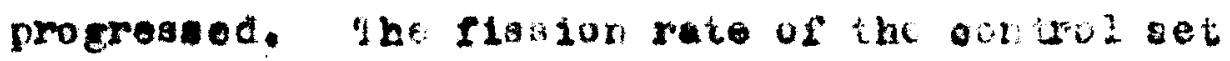
was at anch higher mark all ibroughout the palod

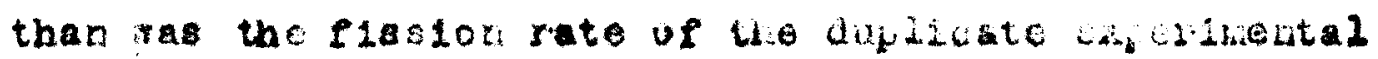




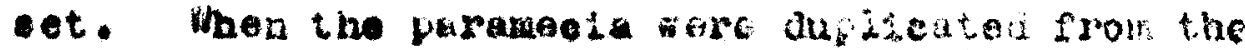
experimertal eot and oultivatod in tha malted wik oultura modum, a pronouneod areet 1n a lon flision

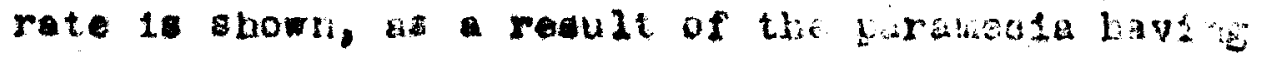
beon flve daje in the vilua nbloride culture rerium. The tive ceye in the oudium choriac oliture medar

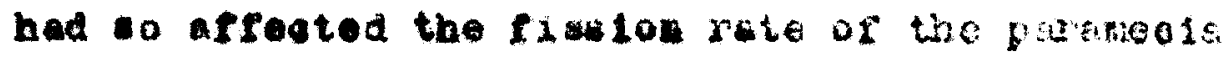
that throughout the naxt twenty deys $1 \mathrm{n}$ the moltod

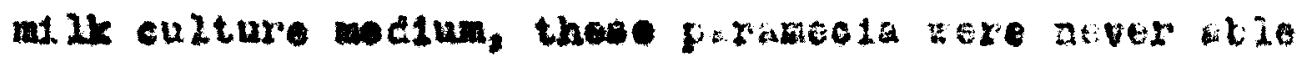

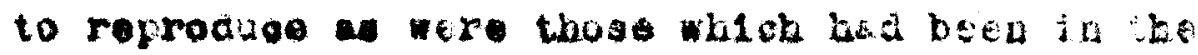
malted nilk oulture medium thoughout tise niole axperimont. Inue the beritable sfoet of the de-

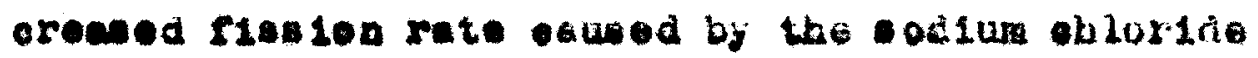
wan demontrated throvghout the tosnty-iay tent portea. 
WXPERIUNWT III 


\section{SXFLKIMEMF III}

A comparison of the piasion Rate of the Duplieate Experiments 2 Set with ihat of the Exporimental set for a Iwanty-Day Ieas Pexiod.

(sept. 30--0ot. 19, 2931)

In this experiment, the fission rate of the duplioate experimental set and of the experimental set contjnued for a period of twenty days. Ihe parameoia in the experimental set had beon runuing for a period of five days before tne $t$ ime of this test period. Likewise, the paramecia in the duplieate experimental set had been hold in the sodium ahloride oulture medium five dsys previous to their transferanee into the malted milis aulture medium. The effect of maintaining the paramecia in the sodium ahloride eulture medium before releasing them into the malted milk culture medium, w1Il be considered In this experiment. Also, the effect of the sodium ohloride on the fission rate of the experimental set and the heritability of that effect will herein be considered. Ihus, paramecia a.ll of the same clone 1n sodium chloride culture medium, will be tested for the effect of tho sulture medium on the fission rate. 
Figure 12 shows the Plvo-dey plastob diferences betweon the dupliat oxprimental and experimental sots for the four frvenda portods. In the rlat period, there was a difforence or 12 flosions; th the second portod, there tas a differeme of 42 flasions; in the third poriod thoro was a differenoe os 54 riasions; and in the fourth period, there was a difference

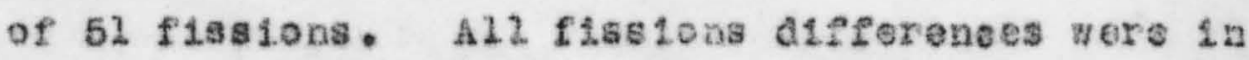
favor of tho duplfoate experinental sot. Lbere ras 2 total excoss of 150 c16310us in the duplioato oxperiment a 2 set. During the first petiod, these wes not aluch a maried luarease in the flastori rate of the capileate experimeatal aet upola its release from the sodium ohloride eulture medilam, bat during the next thres porlods there was a greet iacrease in fission rate. The rission rato in the oxporimextal set tended to steadily daorease as the poriods progressed, resulting in a s lower plssion reto. Iable 8 gives the distribution of the twonty dines, as to atual number of fissions per five-day periods, during the twenty-day test per lod botween the dupli- 


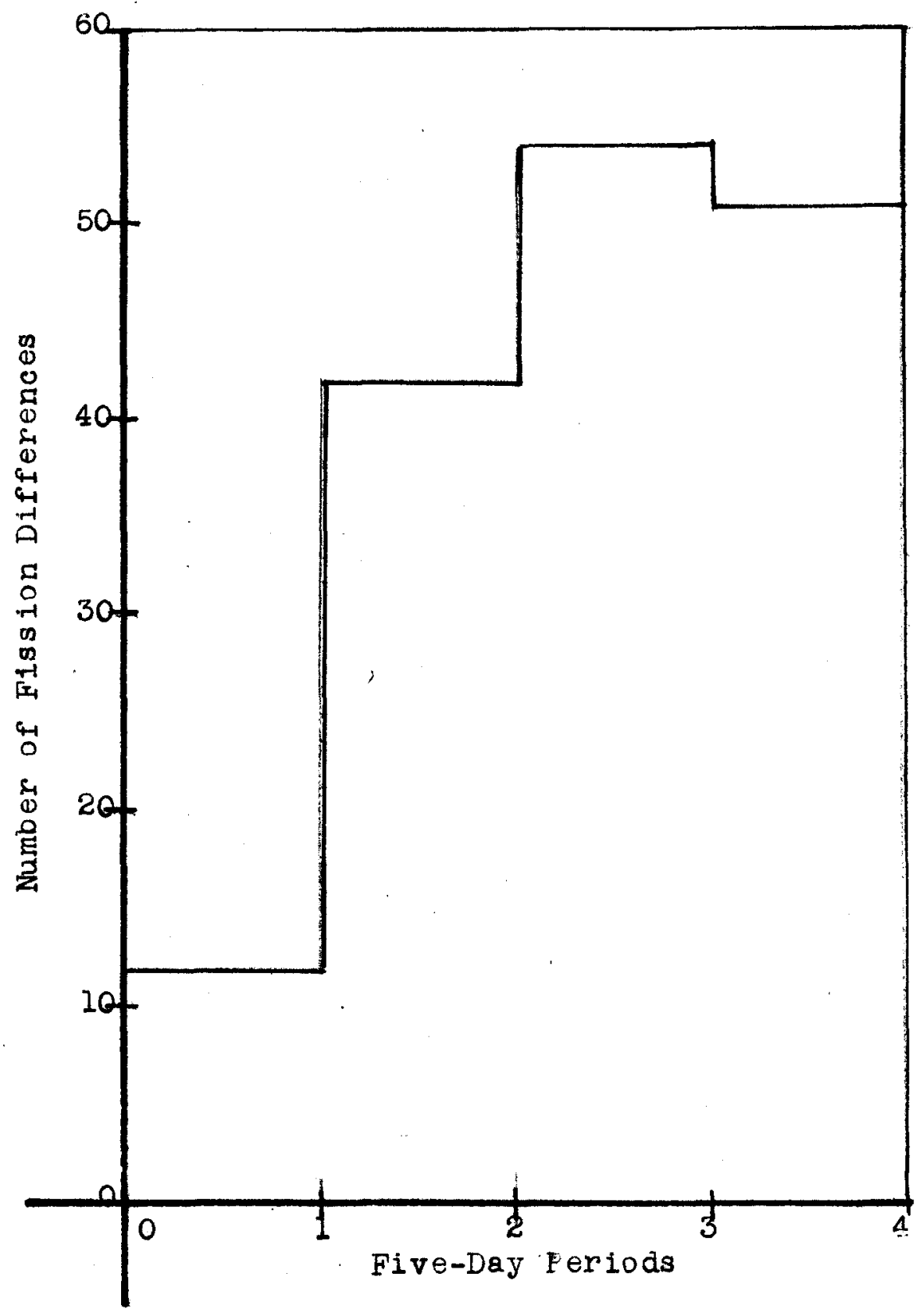

Figure 11. Polygon showing the five-day fission differences between the duplicate experimental and experimental sets.

Excess favors duplicate experimental set. 


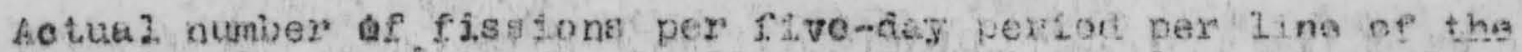

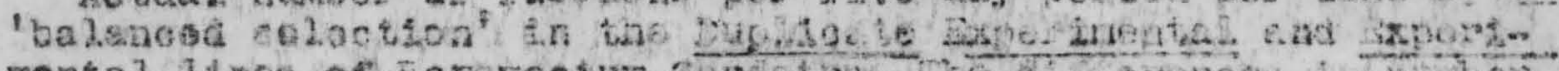

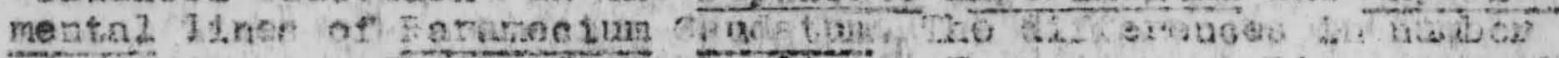
of thaston 27 के pitven.

The average dirforenae in favor of the tho 2 li ate bate rimenta?

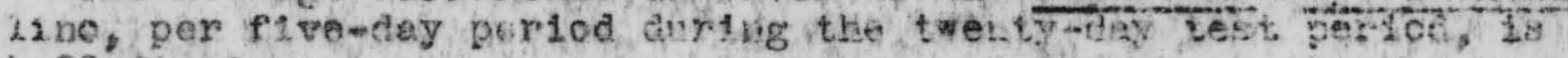
1. 20 ilusune a

Lines ivumer

First onday perioc:

$12 \quad 3 \quad 4 \quad 5$

$8 \quad 7 \quad 8 \quad 9$ 10 10

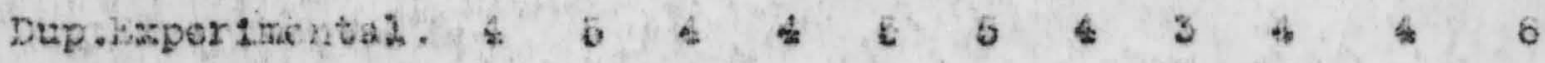
Experimenta2. 6524354034

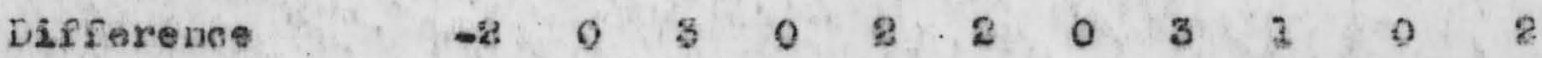

Soouth b-6hy poriob:

Dup. Experimental. $3 \quad 5 \quad 5 \quad 5 \quad 5 \quad 5 \quad 4 \quad 4 \quad 6 \quad 5 \quad 3$ Experimentai

$3 \quad 3 \quad 2 \quad 3 \quad 3 \quad 5 \quad 2$

$\begin{array}{llll}3 & 2 & 3 & 2\end{array}$

Difterenea

$32242022=32$

Thire 5-day partot:

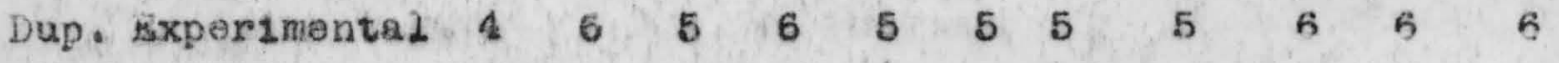
Experimental is 34422232

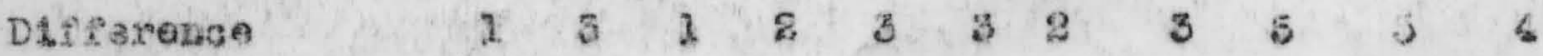

Fourth feciey portor:

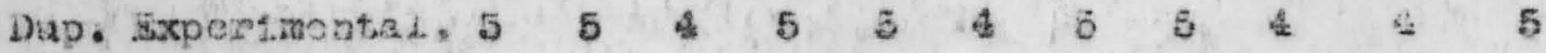

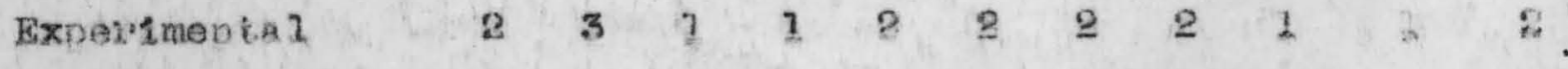

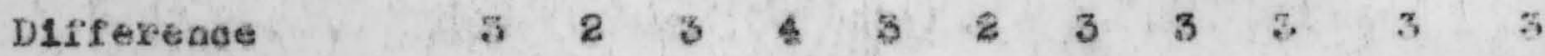

Difierencer fo: the

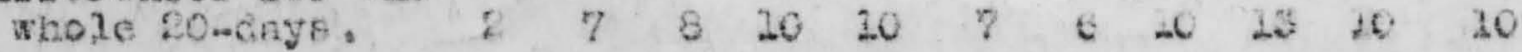


Table 8

In th13 tsble, the numbers in the 'antreremes' colunas ind

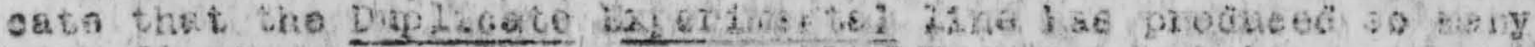

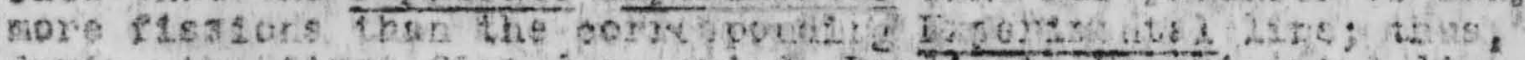

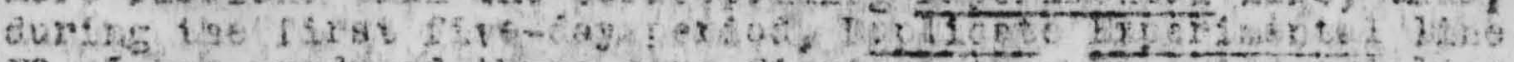

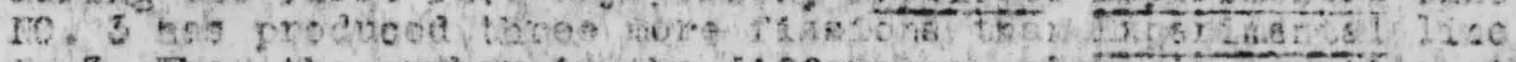

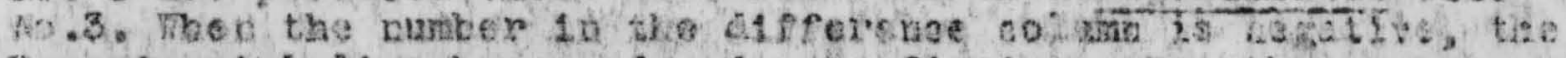

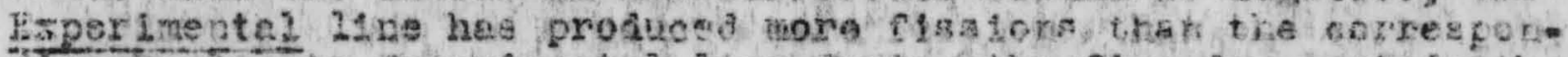

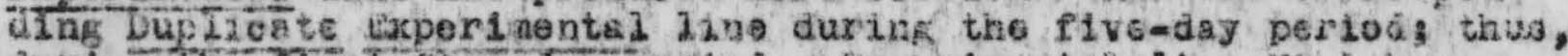

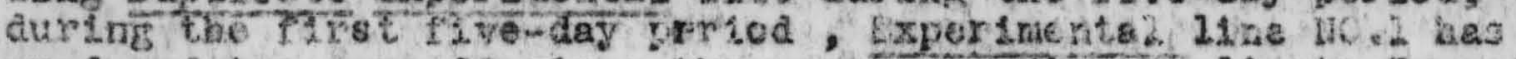

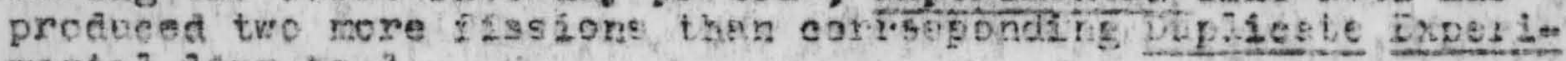
mentaz. 23 ne $\mathrm{HO} .1$.

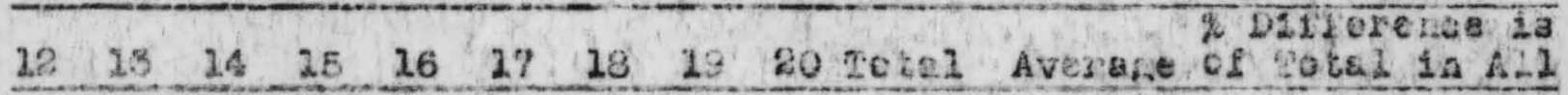

$655: 25345028 \quad 406$

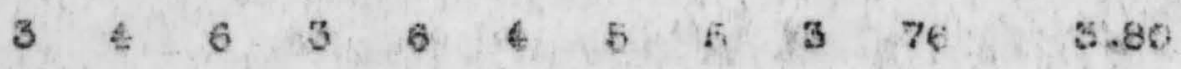

$\begin{array}{lllllllllll}3 & 1 & -1 & 0 & -3 & -3 & -3 & 0 & 8 & 32 & .60\end{array}$

.07

$\begin{array}{llllllllllll}7 & 5 & 4 & 4 & 5 & 4 & 4 & 7 & 3 & 93 & 4.65 & \\ 2 & 2 & 2 & 2 & 2 & 3 & 4 & 4 & 3 & 52 & 2.55 & \\ 6 & 4 & 8 & 3 & 3 & 2 & 0 & 3 & 0 & 42 & 5.20 & \text {.20 }\end{array}$

$\begin{array}{llllllllllll}6 & 5 & 6 & 6 & 5 & 5 & 5 & 6 & 4 & 108 & 5.40\end{array}$

$\begin{array}{lllllllllll}3 & 3 & 3 & 3 & 5 & 3 & 4 & 2 & 1 & 64 & 170\end{array}$

353502254354270 in

$445 \div 545 \% 500 \quad 4.60$

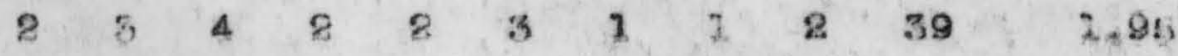

$\begin{array}{llllllllllll}2 & 1 & 1 & 2 & 5 & 2 & 4 & 3 & 3 & 51 & 0.65 & 09\end{array}$

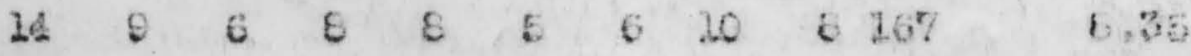


cate exporimeatal sot and the experimental sot, In the duplioste experimertei sot, there were two lines having 4 fisions, four lines hevthg c.25 fiselon, two lines having 1.50 fis 10 as, thrce hines having 4.75 fissions, six lines baving 5 fiseions, whe line having 5.25 fiseloas, oxo liue havag $5.50 \mathrm{fian}$ 3iona, and one line having 5.75 risulua por five day period, making a total of 94.75 fies 20 as.

In the exporimental set, there were two liaes having 1.75 fiesions, tive lines haviag 8.25 fission, four lines heving 2.50 flsalons, two liwes having 8.75 pasions, two lines having 3 fogloge, ole line heving 3.26 flesions, three lines havthg 3.50 f1s. slons, and one line having 5.75 fisslons, making a total of 53.76 fiss 10 as.

Figure 3 (see page 26 ) is a polygon sheasigg the saverage number of IIsajon (averagea for five-dey periods) for the cupliato experimentel and experimental sots. During the filst five-day period, the duplioato exparimental set averaged 17.80 fisisions, while the experimental aet averaged 25.50 fission, leaving a difference of 2 fiss 20 he in favor of the duplioats experineatal zet. The dupliorte experi- 
mental set averaged 28,30 ffasions lurine the segond. pertod, while the experineatal sot avoraged 20.50 flas lons, showing en Gxoess of 8 plasion for the duplicate exporimental 3 st. In the third pertod. the ouplicete experimental a os averaged Rl.60 fis sions and the experimental set avoraget 11,75 fis.. sions, makiag differenee oi 2,75 tisstons fa favor of the diplleate expextmentah set. The bupliceto exporimental set during the fourt pertod avorage 28 fisaions, whize tho ex: Eximetal set averaged 7,75 fiseions, leavine a differeace in favor of the duplacate experimental set of 10.26 plsatona, whe excess in fissioa pate everaged for five-day periods wes 30 fiestong.

F1 gure 6 (sqe page 33 ) ahows the daly asfferences in fisaion rate th the duplioate exporinentad and experimental setr. The duplionte experimental get shell be called aet 2 , asd the exparimental sot shatl be called set a. On tho firvt daj, set 1 bad 12 fisstons, aet 2 had 12 fisstons; on the seond d9y, set 1 had 13 fissione, set 2 had 27 fisespas: on the third day, aet 1 bad $18 \mathrm{ftos} 10 \mathrm{~ms}$, sot \& had 19 . P1su10ng; on the fourth day, sot. 2 has 25 f1.stons 
set 2 had 12 fisalong; on the elfth tay, get 1 had $20 \mathrm{fis}$ sions, set 2 hed $17 \mathrm{fiss}$ sons; on the $81 \mathrm{xth}$ cay, set 1 had 28 figsions, set 2 had 21 fasalogo; on the seventh day, set 1 hed 22 f 18010 no, ogt 2 hsd 12 fissions; on the eishth day, set 1 hac 22 etsolons, set, 2 bad 8 fissions; on the binth day, set 2 hos 18 Plasions, set 2 had 10 fissions; on the tenth says set 1 had $23 \mathrm{flss}$ lons, set 2 had no flsalons; on the eleventh day, set 1 had 25 fisaions, sat. 2 had 2. fisalon; on the twelfth day, set 1 bad 27 f1s:10ns, set 2 had 28 fiss lons; on the thirtesth dey, 381 ? hed 27 flssions, set 2 had 22 fissiong; on the fourm teenth day, sot 1 had 29 fisstons, set 2 hed 1 fission; on the fifteenth day, at 2 had 20 fis 3 ion, set 2 had 18 elssions; on the sixteenth dey, set 1 hed 26 flssions, set 2 had 7 I1ssions; on the seroatecath dey, set 2 had 27 fissions, set 2 bac 7 flagions; on the eighteenth day, set 1 had 18 flssions, set 2 had 4 flssions; on the nineteenth day, set $l$ had $19 \mathrm{ftam}$ sions, set 2 had 7 fissions; on the twomtioth isy, set 2 had 20 fissions, set 2 had 14 fisalons. On the seopod, third, and sixth day, the flssion rate of set 2 exceeded that of $30 t$ i by 4,1 , end 3 fissions respeotively. $u_{n}$ the remaining seventeen days, the PIssion rete of set 1 excoeded thet of set 2. 
Figure 22 is a ourve of the dalizy differences between the average number of fles loid produeed by the

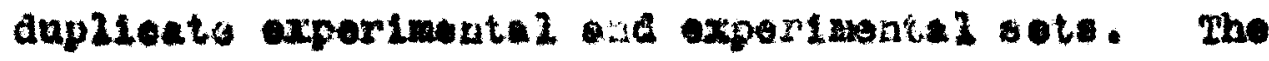
average differonees in ruction of genoration, In favor of the duplsecte exparimextal sot, are hown. on the firet day there sas alfferente between the

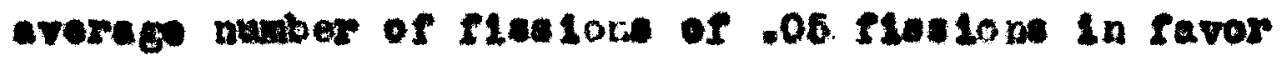
or the dupllokte expertmontal set, if ristons dirforenoe on the seopol aty in favor of the experimeatal sot.

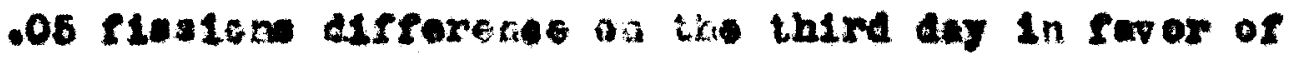
the exporimovtel aot, .68 ilad 10 na differone on the

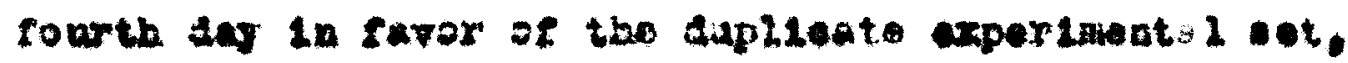
.26 siandos alfereno aid the firth dey in fapor of

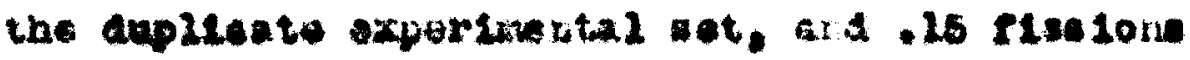

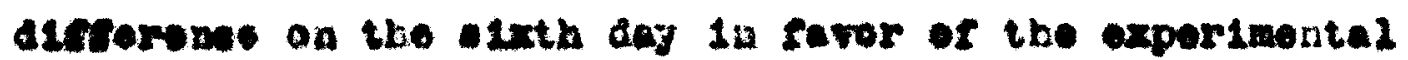
et. For the remalinear of the trenty-day portod, the alferenon in fineion rst betwen the average number of elestore of the tao sots is in farer of the aupliente experimental set. Thee differanee are

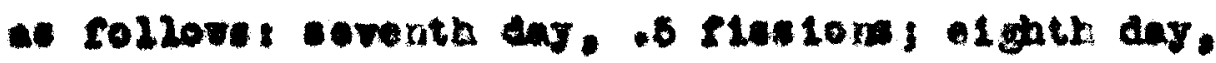

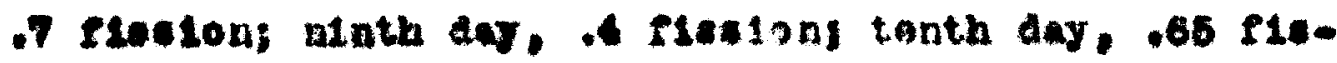
alons thirteonth day. .86 fisclonf fourtesuth day. 1.4 fieslon! fiftenth dy, 2. risalom, alxteenth day, .45

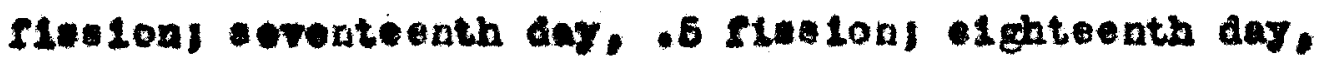
.7 realons nimeteenth day, .6 fiastons and twentioth 


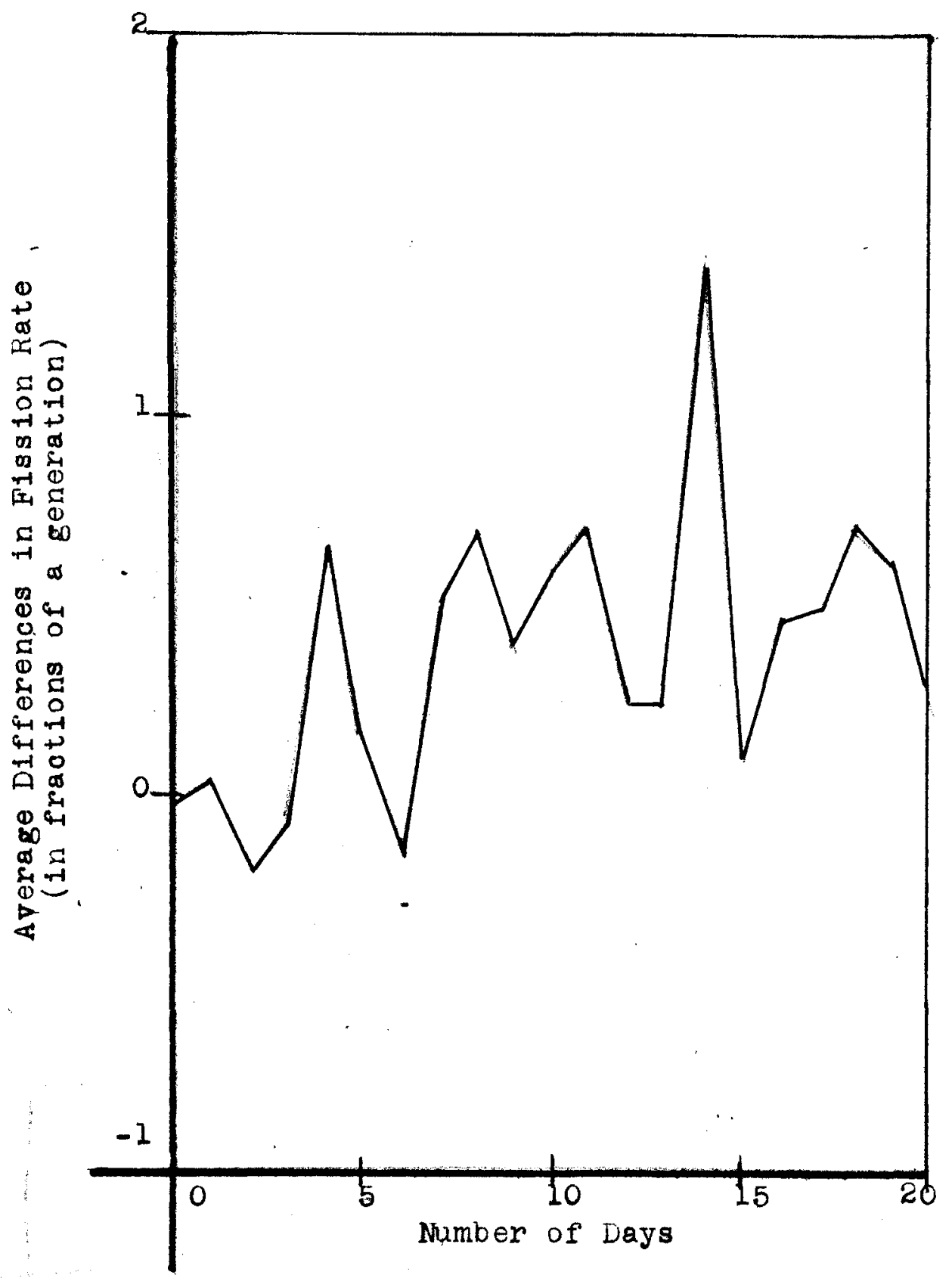

Figure 12. Showing the curve of the daily differences between the average number of fissions produced by the duplicate experimental and experimental Iries.

kxcess in fission rate is in favor of the duplicate experimental ines. 
day, .3 rision.

P1gure 2318 the curve of varlatson in average I1ro-day flasion of tho twenty duplleate experimonted and the twenty exporimontal 210ee during the twontyday toet poried.

The ourve of variation in averuge five-day f1sslone for the duplieate experimental 21 nes ranges from 4 to 6.7 flus $10 \mathrm{ne}$. Fhere were two $21 \mathrm{me}$ heving

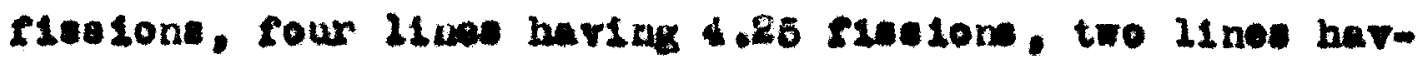
Ing 4.6 flesions, three lines baving 4.76 rlesione,

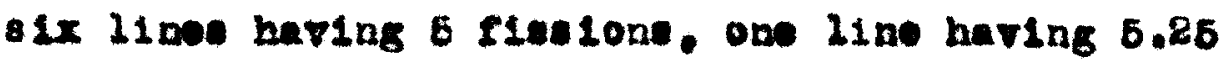

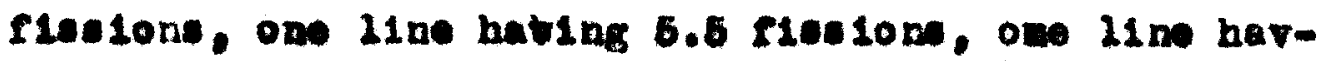
Ing 6.76 fles lone.

The ourve of varlation in arorage f1re-day f10810 no for the experimentel 21 ne range from 2.78 to 3.76 fiestone. ghere were two 21 be having 2.76

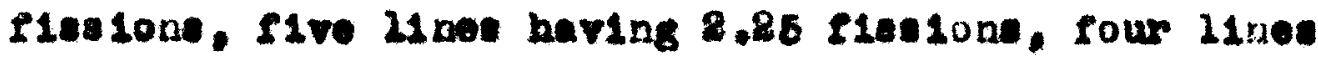
having 8.60 flevtorn, two 21 es baving 8.75 fiek lone. two 21 nes baring 3 flestons, one lins having 3.26 s1estors, three 21 noe having 3.60 ries $10 \mathrm{ne}$, and on line having 3.76 riesions.

The flas ion range for the duplieate experimental wet wa wuoh lower than that for the experimental set. In the deplloate experimental set, there were $81 x$ IInes harlng in the average fivemday rate, 6 flesions. 


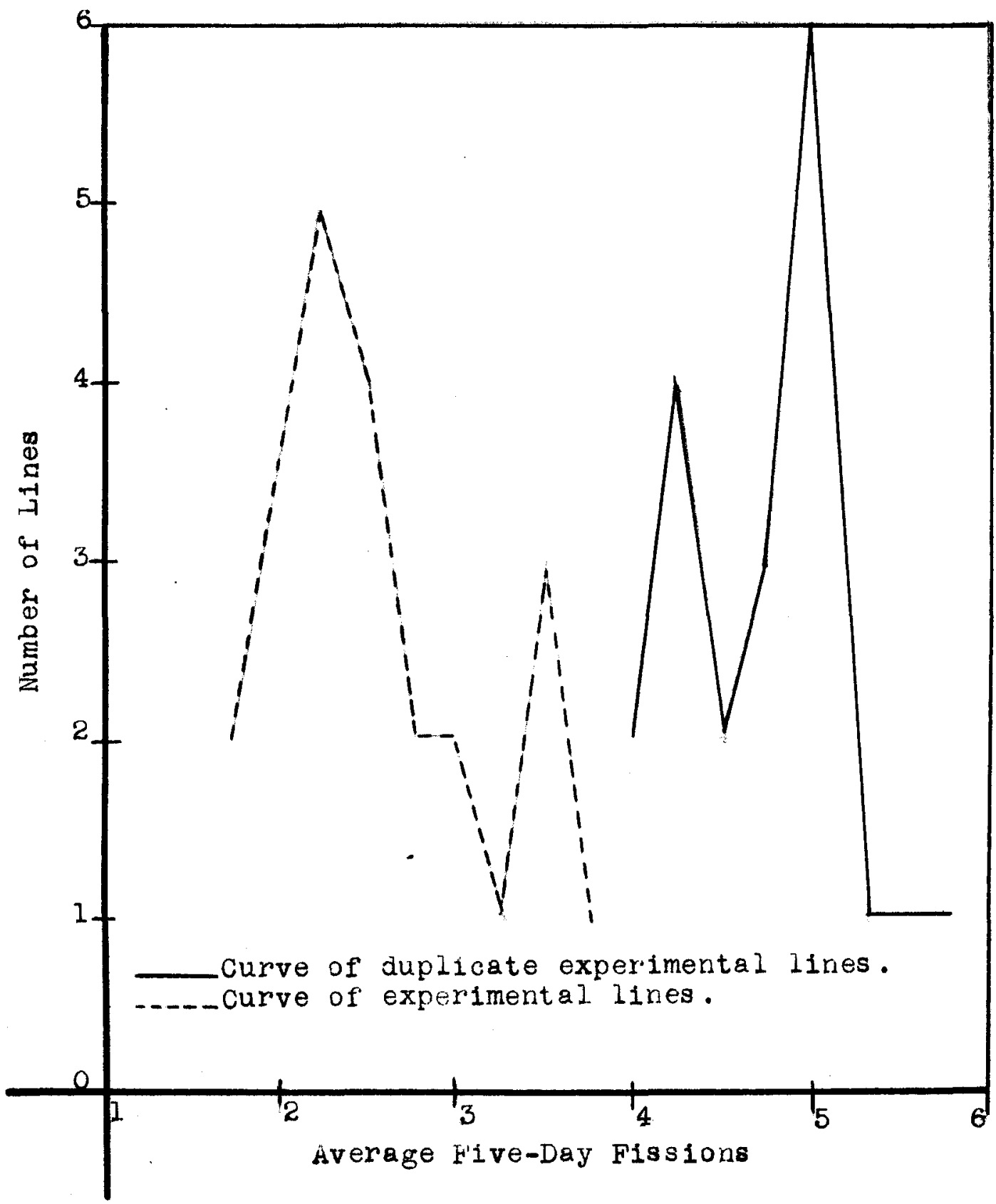

F1gure 13. showing the curve of variation in average five-day fissions of the duplicate experimental and experimental lines during the twenty-day test period. 
In the axperimental at, there were five inger ith

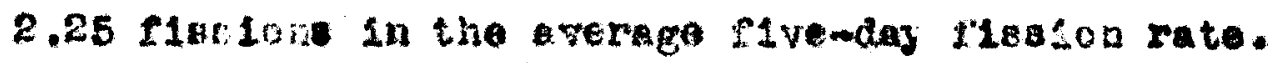
mab2e 6 (aso pege 67) alves the aotual number of elesions por flveday period per libe in the dup11oute exporimental and oxperimentul cos. Tho difforenoes In nubor of fiasions in favor of the duplionte axperimontal 11 nos are nleo efren.

During the eingt firemary forlod, there fae a total for the tronty linos ia the dupisente axperimental aet of 88 : fsosona, Gid a total for the

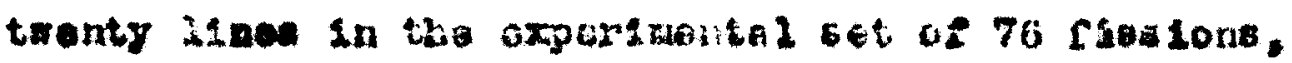
leaving a alffortase of 20 faglone in favor of the duplieate exparluertal set. Darling the esrot fire

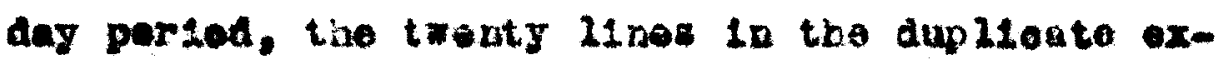
perimental eat areragea t.40 fiss $20 \mathrm{ng}$. while the twonty 21 nos in the experimortal cot averaged 3.80 f1asiono, Leating a alfenronce of .60 flesion in farer of the tupleate oxperimatal aot.

Durlng the aneond fivedey period, thexe way a total for the trenty ine in the duplieate sxperimental cet of 03 elasions, and a total for the tranty Inos in the expertiontad ot of 51 fisc 20 n. learing a differenae of 42 finsione. During this nooond perlod, the trenty 2 ines in the cuplicate oxporimental 
Table 6

Distribution of libes, an regarda arorage nuver of fiaston in tho duplionte expertmovtal and experimental 21 neo during the twouty-day teat period.

Tho fls: Lous are averaged for flvomag portodo.

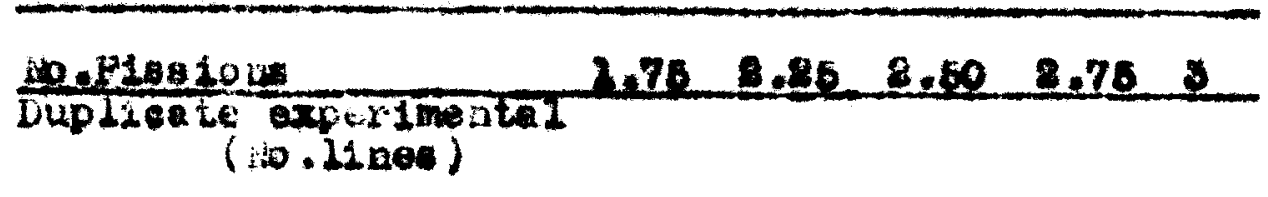

Expoributitai

(ib.Line) 80648

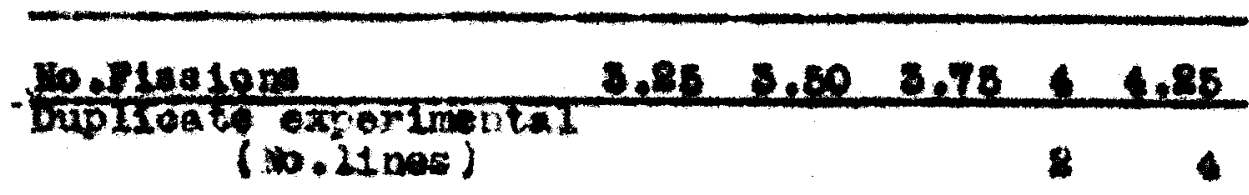

Steperimontal

$(10.21000) \quad 2 \quad 3 \quad 2$

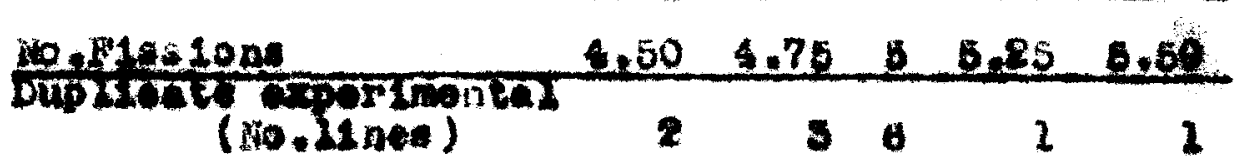

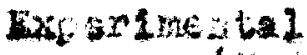

(10.14nes)

\begin{tabular}{|c|c|c|}
\hline 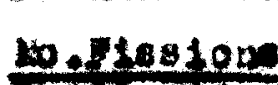 & 6.76 & $10 \operatorname{co} 2$ \\
\hline bupusente & 2 & 04.76 \\
\hline Dportmerta & & 65.76 \\
\hline
\end{tabular}


set averaged 4.66 flostons, wh12e the twenty 11 nes In the experimental aet ureraged 2.56 flas 10n, leav1ng a dfferenoe of 8.20 fies 10 ne la faror of the duplionte exportmental sot.

During the thind s1readay perlod, thore was a total for the trouty Ilden la the dapdsate experi-

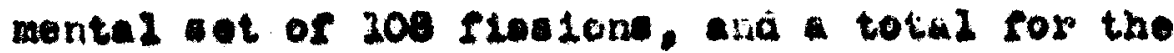

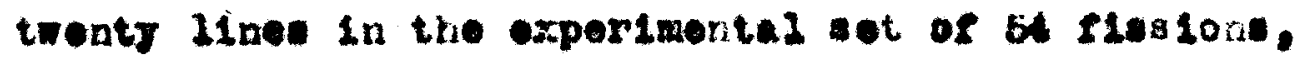
learlag a differenee of be flacion. During this perlod, the dupl10ate exporimoutal sot averaged 5.40 f1s 10 a, whilo the experine:2tal set averaged 2.70

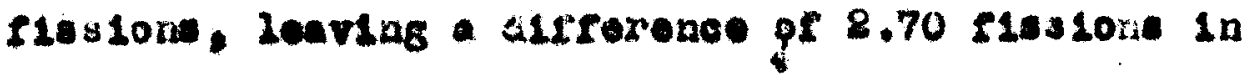
faver of the aupliente axperinental not.

During the sourth rive-day porlod, there was a total for the twenty ines in the dupliento experi-

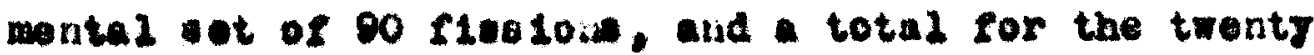
IIno in the experimaiter sel of 39 flesione, 2eavIng a differenoe of 52 flasione. Ize duplloato experinontal eet areraged 4.60 \$24820na, wh120 the expertwental set averaged 1.95 fleg Lono, leaving defforenoe of 8.56 risstons do laver of the duplloate experimontad set.

Por the four r17e-day porlods, there was a total 
difference of 167 fisolon in favor of the dupjlonte experimethal net axd on averuge differenoe of 8.36

fiesion, Le 1ri favor of the alipldent experimental sot.

The average differenoe in fiasion rate in faver

of the cup zlonte experimentaz eet, por fire-day feriod during the tmontymang teat poriod, was 2.00. 
STWMALS

I 
In Faramecium eaudatur, by 'balanood soleotion' through many generations resulting from a single individual, it was posibie through the use of the two different oulture medis, to produce two sets differIng horeditarily in rate of ftesion. During this 'balabeed seleotion", thore was a gradual lnerease tin average heritable results in the eontrol set of I arameda ecudatur. The sodium chloride had a certain definite effeot on malntsining at a lowerod rate, the fluston awoug the paramedia of the sxpertmental set.

Whis heroditary trati of a deoreased fission rate due to the eavironmental factor of the sodium ahloride peraisted throughout the period, and even persisted when the environmental factor was removed, and the coatrol oulture mediun substituted. Ihe hersaftary differonoes of the 'mazted milk' and 'sodium chloride" acts continued throughout the entire period of "Dalaneed selection"; the hereditary differences of the 'sodium chloride' set ald not disappear when chese parameeia ate changed to a 
malted milk eulture mediurn.

Thus in Parameois saudatum, from a single clone of given genotype, it is possible to obtaln through a long period of 'balenoed seleotion' during reproduction by fission, two sets of diverse genotypo, differing charsetaristiesily from each othar in rate of riesion, under dissimilar ovlture media, snd retainIng these differences from generation to geceration. 
73

BIBLTOCRAF FY 
2. Bovie, W.I., and Hughes, D.t. The efreta of fluor1te ultra-violet rays on the rate of divialon of Peruneelug. Jour. Mod.ñes enrob s9. 233-238. 2018.

2. Bulliagton, W.F. A further study of splruling in

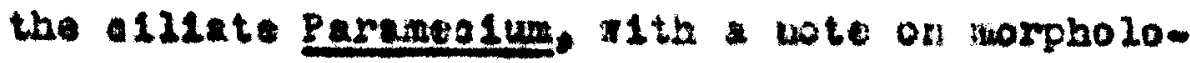
cy ad laxonomy. uxp. 2032. 53! 423-449, 2030.

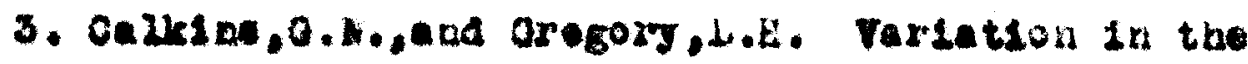
proten of a lagle exoonjugaut of Earamelum sudatua. Jour. 2xp. 2082. 161 467-625. 2923. 4.0012ett, M.I. The toxielty of slas to 1afusoria. The role of ta toleoule and lona. Jour. 5xp. 2082, 34: 67-74. 2282 .

6. Devivey. E. Coatributlone to the phylo208y of Para-

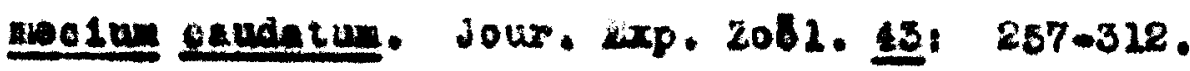
2028.

6. Fetter,D. Deterultation of the protoplesmie viscos1ty. Jour. by.2012. 44: 279-283. 1026.

7. Fluther. M. I. Iflustos of glasular extracts upon

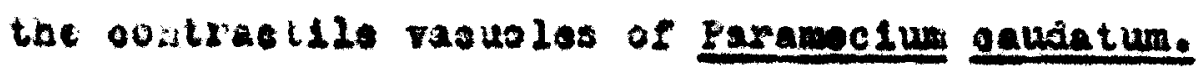
4101. EuL1. 37, 22-38. 2510. 
8. Glanor, $c$. Temperature and formal novoment of Bararsoc Lua. Four. Gor. Phy 101. 7; 177-188. 2024.

9. Hopkins, E.E. The condtione for conjugat1on in diverse races of Paremechum. Jour. Exp. 3032. 34: 389-384. 28E2.

20. Hutchlnoon, $k+5$. The efect of cirtaln salta and of adaptation to ilgh teaporature on the heat

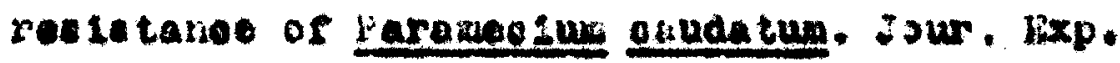
3082. 28: 822.226. 2026.

22. Jouningo, H.S. The effoct of conjugation in pareo neelum, Jour. Mxp. zob2. 24: 879-302. 1923.

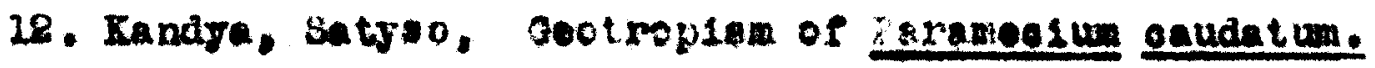
B102. Bu22. 341 208-228. 2029.

23. Landya, sutyco, kelet1ow of oxitat10n in Earemeolum abudatur and It Indopendence of the toxication

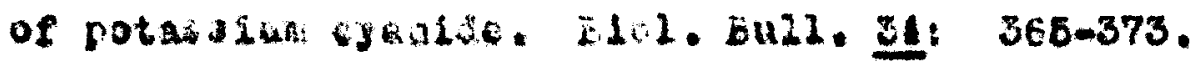
2028.

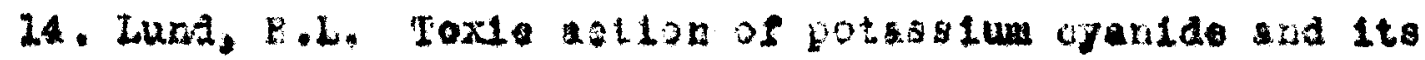
relation to the stste of tatrition and age

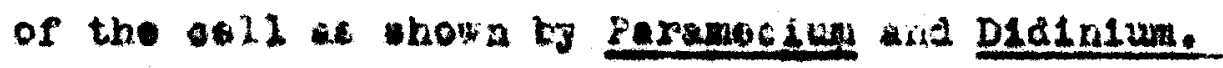
BLO2. EL12. 30! 222.231. 2918. 
15. liaupas, E. Experimental researches on the multiplidetion of elilaked infusoria. Exp. Zobl. 2: 265-277. 1318.

i6. Watieton, A.R. hor table vercations and the results of atestion sn the fisstur rate of Styloryohia pustuketa. Jour, Exp, Z081. 2.8: 451-503. 1928.

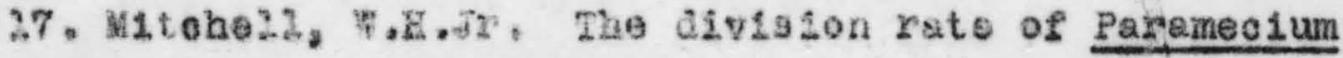

An relatson to tompersture. Jour Exp. Zobl.

54: $547.664 . \quad 102 \%$.

18. Nyers, Evoratt G, Relation of Eensity of population and certein other fsotors to survival and reproauot ton in sifforent biolypes of Paramecium cauEstun, Jour, Exp. Z09L, 49: 421-438. 1927. 12. Pakert, $c$, The erfact of light on the permerablity of Paramesus, Jour, Gon, Pays101. 7: 367-372. 1925,

20. Pagkark, R.C. The effoct of aelestion in pedigree 31rea of 1nfusorsa. Jour. Exp. Z081. 49: 2 1327 ,

21. Psobles, $F$, Regonerat 10 and regulation in paramecium gaudatus, B101, BuIl, 23: 154-170. 1912. 
2E. Jhumay, R.C. The oreote of a thyroll diet upon Paxkmegim, Jour, Kxp. Z0152, 28: 528-563. 2.92 .7 .

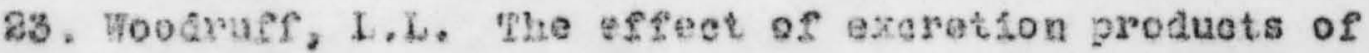
Persmeolum on 129 rate of regrobuetion. Jour. 4xp. $2082 . \quad 201$ 557-582. 2826.

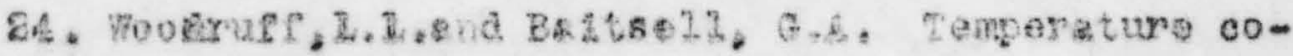
efrioboot of raie of renrobuotion of Earsmeoium suxe12a, Aras, Jour. : hy 702. 2.92. 247-255. 3.920.

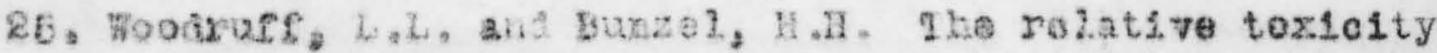

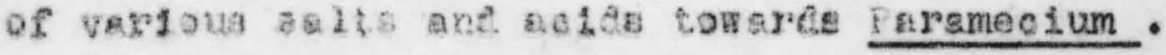
Aner. Jour. Fbys:02, 2: 565 2920/

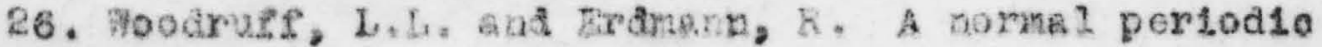

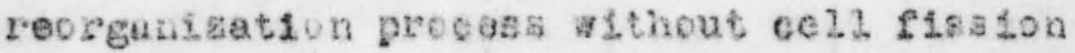

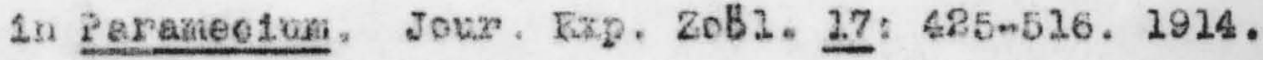

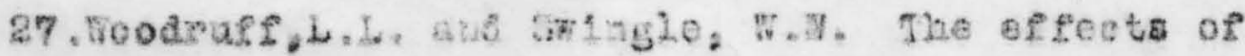

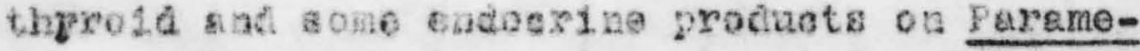
Clur. Amern, Jour, Phys101, 68: 645m648, 1924. 26. Young, R.I. Treerlnguta? 1 uqution of encomixis in

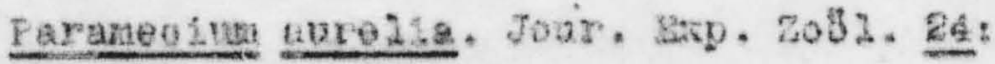
$35-53 . \quad 2927$. 